\title{
Ecological connectivity of the marine protected area network in the Baltic Sea, Kattegat and Skagerrak: Current knowledge and management needs
}

\author{
Charlotte Berkström (D), Lovisa Wennerström, Ulf Bergström
}

Received: 9 June 2021/Revised: 8 November 2021 / Accepted: 29 November 2021 / Published online: 29 December 2021

\begin{abstract}
Marine protected areas (MPAs) have become a key component of conservation and fisheries management to alleviate anthropogenic pressures. For MPA networks to efficiently promote persistence and recovery of populations, ecological connectivity, i.e. dispersal and movement of organisms and material across ecosystems, needs to be taken into account. To improve the ecological coherence of MPA networks, there is hence a need to evaluate the connectivity of species spreading through active migration and passive dispersal. We reviewed knowledge on ecological connectivity in the Baltic Sea, Kattegat and Skagerrak in the northeast Atlantic and present available information on species-specific dispersal and migration distances. Studies on genetic connectivity are summarised and discussed in relation to dispersal-based analyses. Threats to ecological connectivity, limiting dispersal of populations and lowering the resilience to environmental change, were examined. Additionally, a review of studies evaluating the ecological coherence of MPA networks in the Baltic Sea, Kattegat and Skagerrak was performed, and suggestions for future evaluations to meet management needs are presented.
\end{abstract}

Keywords Connectivity · Dispersal .

Ecological coherence $\cdot$ Migration .

Marine protected areas (MPAs) $\cdot$ Mobile links

Supplementary Information The online version contains supplementary material available at https://doi.org/10.1007/s13280021-01684-x.

\section{INTRODUCTION}

Ecological connectivity promotes persistence and recovery of marine flora and fauna by the dispersal and movement of organisms and material across populations, communities and ecosystems (Balbar and Metaxas 2019). Connectivity may, however, also promote spread and range shifts of species that invade new areas with negative effects on native ecosystems (Holopainen et al. 2016). Movement and dispersal of eggs, spores, larvae and older individuals among spatially distinct entities is often referred to as ecological spatial connectivity (Carr et al. 2017; hereafter connectivity) and is highlighted as an important element in the design of ecologically coherent networks of marine protected areas (MPAs) (Balbar and Metaxas 2019). MPAs have become a key component of conservation and fisheries management and is recognised as a primary management approach in attempts to alleviate anthropogenic pressures and ensure sustainable use of marine resources (Lubchenco et al. 2003; Halpern et al. 2010). MPAs can also play a vital role in climate change adaptation by enhancing ecosystem resilience and protecting vital ecosystem services (Micheli et al. 2012; Carr et al. 2017). MPAs with fishing restrictions may further enhance density, biomass and body size of targeted fish species and restore ecosystem structure and function (Lester et al. 2009; Baskett and Barnett 2015). MPA size and placement are, however, considered critical elements affecting the success of MPAs, as is the connectivity between the individual MPAs in a network (Claudet et al. 2008; Molloy et al. 2009; Vandeperre et al. 2011). The rate of MPA establishment is increasing worldwide as a response to the 2004 decision by the UN Convention on Biological Diversity to achieve effective protection of $10 \%$ of marine ecoregions and that MPAs should be ecologically 
representative and well connected. Additionally, a resolution for a new global target of $30 \%$ protection was adopted by IUCN in 2016, and is also a central part of the new EU Biodiversity Strategy for 2030 (European Commission 2020). For an efficient expansion of the MPA network in Europe and worldwide, there is a need to evaluate the ecological coherence, including aspects of connectivity and representation of crucial habitats and species. Evaluating ecological coherence of MPAs and MPA networks is, however, still in its infancy and information on connectivity has so far rarely been used in the design and development of MPA networks.

There is no set definition for ecological coherence, although a number of criteria can be quantified during assessment; (1) adequacy, (2) representativity, (3) replication, and (4) connectivity (Ardron 2008; Sundblad et al. 2011). Adequacy means that the MPA should be of appropriate size, shape and location to maintain ecosystem functions and services. Representativity reflects the proportion of each conservation feature, while replication reflects the number of each conservation feature being protected. Connectivity, in turn, refers to the spatial configuration of the MPA network and the potential for organisms to move between the individual MPAs and other suitable habitats outside the MPA network to maintain functioning meta-populations. In some cases, only habitat within MPAs are considered when evaluating connectivity, the so-called scorched-earth-scenario (Allison et al. 1998; Jonsson et al. 2020). However, viable habitats outside the MPA network may act as stepping-stones for dispersal where MPAs are part of a wider meta-population. Connectivity may also involve the movement between habitat patches within an MPA during various life stages (ontogenetic migrations). It filters through all the above criteria since dispersal or these active migrations will also affect what size, shape and location of an MPA is required in order to protect the species, as well as which habitats to include and in what proportion. This highlights the growing need to evaluate the ecological coherence of MPA networks based on connectivity via active migration and passive dispersal by a range of species (Virtanen et al. 2018; Jonsson et al. 2020). We have reviewed current literature (grey and white) on ecological connectivity and ecological coherence of the MPA network in the Baltic Sea, Skagerrak and Kattegat. The Baltic Sea is a particularly interesting regional sea regarding future management actions because many pressures and impacts are exceptionally severe. At the same time, these pressures are targeted by an internationally advanced governance and management in order to mitigate negative effects, which is relevant also for other regions where international cooperation is needed to meet environmental challenges. The Baltic Sea also stands out in providing accessibility to long-term data series and a strong scientific foundation, providing a unique opportunity to assess the efficacy of management actions (Reusch et al. 2018).

\section{METHODS}

In order to summarise information on ecological connectivity in the Baltic Sea and studies testing the ecological coherence of the MPA network, searches were done in Web of Science with a combination of words including: connectivity, dispersal, home range, fish migrations, nursery, spawning, tagging, and ecological coherence (search strings in Appendix S1). Relevant home pages and databases including governmental, regional authorities, NGOs and universities were also scanned in order to find reports and grey literature and researchers with relevant knowledge from the study region were contacted to identify additional literature on connectivity. Information was summarised based on species-specific distance measures for:

(1) active migrations (home ranges),

(2) passive dispersal of eggs, larvae, spores and/or,

(3) distribution ranges based on genetic studies.

In cases where maps on dispersal were available, but no distances were stated, we measured approximate maximum distances for larval dispersal using the Google Earth geographical information system, based on models and maps from Hinrichsen et al. (2017b) and Florin et al. (2013), which included maps for Atlantic cod (Gadus morhua), European flounder (Platichtys flesus) and turbot (Scophthalmus maximus).

In order to search for genetic connectivity the search string "genetic* AND (differen* OR structure OR divergen*) AND (Baltic Sea)" were used. Measures on connectivity, migration distances or distribution ranges were identified. In studies where the authors stated a distance at which migration or gene flow occurs or where populations significantly differ, this distance was set as the maximum range. In cases where distribution ranges or differentiation among populations were described in figures or tables, maximum distances of population distribution were measured in Google Earth.

\section{ACTIVE MIGRATIONS AND PASSIVE DISPERSAL}

Connectivity in aquatic environments can be maintained either by active migrations of adult and juvenile organisms or by passive dispersal by currents of eggs, larvae, spores, seeds and fragments. Macrophytes, macroalgae and invertebrates may also disperse by attaching themselves to 
floating objects (Källström et al. 2008; Winston 2012). Many fish and invertebrates have a pelagic larval phase, spending several weeks in the pelagic zone, and thereby dispersing ten- to hundreds of kilometres (Fig. 1; Kinlan and Gaines 2003). For example, the females of edible crabs Cancer pagurus can migrate $100 \mathrm{~km}$ upstream to spawn and consequently larvae disperse more than $100 \mathrm{~km}$ downstream along the females migration path (Ungfors et al. 2007). Some invertebrate species, however, like the polychaete Hediste diversicolor lack a pelagic larval phase and hence have very limited dispersal of only a few metres (Einfeldt et al. 2014).

Macrophyte and macroalgal seeds and spores generally have a more limited dispersal range $(<10 \mathrm{~m})$ than fish and invertebrate larvae (Fig. 1, Table 1). Seeds and spores from sexual reproduction are often heavy and sink within meters of the mother plant, limiting dispersal. However, in some cases, parts of the algae may break off and float long distances before attaching to the bottom in areas with optimal conditions (Tatarenkov et al. 2005). This asexual strategy is a way for algae to increase dispersal and can be found in e.g. bladderwrack, Fucus vesiculosus (Rothäusler et al. 2015) and its sister species $F$. radicans, endemic to the Baltic Sea. In fact, this is the main dispersal strategy for $F$. radicans living on the border of its distribution range, which is reflected in its genetic composition where most plants belong to a single clone (Ardehed et al. 2016). In some cases, reproductively mature thalli can also break off and release their gametes in a new location, with potential for long-distance gene flow. Shoots with seeds that have

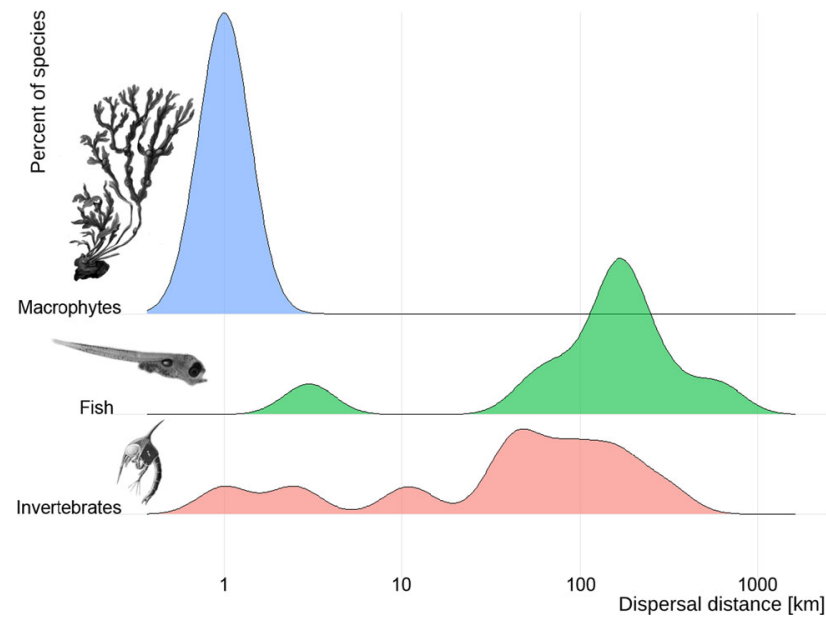

Fig. 1 Dispersal distances for spores and pelagic larvae from macropyhytes, invertebrates and fishes in the Baltic Sea, Kattegat and Skagerrak. Distances are maximum distances derived from Table 2, a summary of distances derived from a literature review. Information on dispersal of species with short pelagic stages is limited and hence the number of species with short larval dispersal distances is likely underestimated in the figure. Figure adapted from Gaines et al. (2007) naturally detached from eelgrass (Zostera marina) have also been found to float for months, during seed maturation, covering large distances $(>100 \mathrm{~km})$ in Kattegat-Skagerrak and contributing to long distance dispersal (Jahnke et al. 2018). This type of dispersal is, however, not very common in the Baltic Sea where eelgrass blooms more seldom and may, just like for $F$. radicans, be due to the benefits of asexual reproduction when living in environments close to its physiological limits. However, MartínezGarcia et al. (2021) recently found that sexual reproduction in eelgrass might be common up to the Bornholm Basin at the southern Swedish coast, where a high percentage of multi-locus genotypes were found. Macrophytes and macroalgae may also disperse far by hitchhiking with fish (Boedeltje et al. 2015), birds (Hattermann et al. 2019) or birds feeding on fish (King et al. 2002; Leeuwen et al. 2017). Intact seeds from a number of macrophytes have been found in the faeces of carp feeding on macrophytes and in faeces from cormorants feeding on herbivorous fish. Live fish embryos have also been found to survive gut passages in waterbirds, providing evidence for bird-mediated dispersal of fish (Lovas-Kiss et al. 2020).

Dispersal by pelagic larvae is more common in marine species compared to freshwater species and is therefore a common feature in Kattegat and Skagerrak while less so in the brackish Baltic Sea, which possesses a unique set of species of both marine and freshwater origin. Roughly $70 \%$ of marine invertebrates and the majority of marine fish disperse by larvae (Thorson 1950). Species in the Baltic Sea of marine origin, e.g. cod (Gadus morhua), sprat (Sprattus sprattus) and flatfish, often spawn in the pelagic zone and have larvae dispersing far with currents during 1-2 months. They also tend to be more mobile as adults with cod migrating up to $1000 \mathrm{~km}$ (Table 2). In contrast, species of freshwater origin like pike (Esox lucius), perch (Perca fluviatilis) and pike-perch (Sander lucioperca) tend to spawn closer to the coast in shallow, warm macrophyte habitats during spring where eggs are attached to vegetation or are stationary until they hatch (Table 1). Additionally, these species often have small home ranges, staying close to the coast while marine species tend to migrate long distances (Fig. 2). A reason for this difference is that the Baltic Sea is characterised by strong environmental gradients including temperature and salinity and many species are highly dependent on specific environmental conditions for development and survival during larval- and juvenile stages (Aro 2002).

Salinity declines in a gradient towards the northern parts of the Baltic Sea, limiting dispersal and survival of marine species and hence acting as dispersal barriers. Temperatures also fluctuate greatly on a yearly basis due to shallower water in the Baltic Sea compared to the deep North Sea (Bekkevold et al. 2015; Berg et al. 2017). These 
Table 1 Summary of distribution and habitat use by species from the Baltic Sea, Kattegat and Skagerrak for which published information on dispersal distances is available. See Table 2 for dispersal distances. $\mathrm{G}=$ Gulf of Bothnia, $\mathrm{B}=\mathrm{Baltic}$ Sea, KS $=\mathrm{Kattegat}-\mathrm{Skagerrak}, \mathrm{C} / \mathrm{L}=$ coastal/littoral, $\mathrm{B}=$ benthic $(>20 \mathrm{~m}$ depth), $\mathrm{P}=$ pelagic, $\mathrm{A}=$ adult, $\mathrm{J}=$ juvenile, $\mathrm{S}=$ spawning. Habitat acronyms: $\mathrm{SH}=$ shallow, $\mathrm{D}=$ deep, $\mathrm{S}=$ soft, $\mathrm{B}=$ bottom, $\mathrm{H}=$ hard, $\mathrm{M}=$ with macrophytes and macroalgae, $\mathrm{NM}=$ no (without) macrophytes and macroalgae, $\mathrm{P}=$ pelagic. For maraena whitefish, (M) refers to marine (coastal) spawning ecotype and (AN) to anadromous ecotype spawning in rivers

\begin{tabular}{|c|c|c|c|c|c|c|c|c|c|c|c|c|c|}
\hline \multirow[t]{2}{*}{ Species } & \multirow[t]{2}{*}{ Common name } & \multicolumn{3}{|c|}{ Distribution } & \multicolumn{3}{|c|}{ Zone } & \multicolumn{2}{|c|}{ Spawning } & \multirow[t]{2}{*}{ A habitat } & \multirow[t]{2}{*}{$\mathrm{J}$ habitat } & \multirow[t]{2}{*}{ S habitat } & \multirow{2}{*}{$\begin{array}{l}\text { S depth } \\
(\mathrm{m})\end{array}$} \\
\hline & & G & B & KS & $\begin{array}{l}\mathrm{C} / \\
\mathrm{L}\end{array}$ & B & $\mathrm{P}$ & $\mathrm{D}$ & $\mathrm{P}$ & & & & \\
\hline Abramis brama & Freshwater bream & 1 & 1 & & 1 & & & 1 & & SHSB & SHSBM & SHSBM & $0-1.5$ \\
\hline Acipenser oxyrinchus & Atlantic Sturgeon & 1 & 1 & 1 & 1 & 1 & & 1 & & SB & SB & SHHB & $10-20$ \\
\hline Ammodytes marinus & Lesser sand-eel & & & 1 & 1 & 1 & & 1 & & SBNM & SBNM & SHSBNM & $0-10$ \\
\hline Amphibalanus improvisus & Bay barnacle & 1 & 1 & 1 & 1 & & & & 1 & SHHBNM & SHHBNM & SHHBNM & - \\
\hline Anguilla anguilla & European eel & 1 & 1 & 1 & 1 & & 1 & & & - & SHB & - & - \\
\hline Ascidia mentula & Tunicate & & & 1 & 1 & & & & 1 & DHBNM & DHBNM & DHBNM & $5-150$ \\
\hline Ascophyllum nodosum & Knotted wrack & & & 1 & 1 & & & & & SHHBM & SHHBM & SHHBM & $0-2$ \\
\hline Aurelia aurita & Moon jellyfish & & 1 & 1 & 1 & & 1 & & & $\mathrm{P}$ & $P$ & $\mathrm{P}$ & - \\
\hline Cancer pagurus & Edible/Brown crab & & & 1 & 1 & & & 1 & & SHBNM & SHBNM & SHBNM & $10-40$ \\
\hline Carcinus maenas & Eruopean shore crab & & 1 & 1 & 1 & & & 1 & & SHB & SHHB & SHHB & $0-30$ \\
\hline Ciona intestinalis & Vase tunicate & & & 1 & 1 & & & & 1 & HBNM & HBNM & HBNM & $0-500$ \\
\hline Clupea harengus & Atlantic herring & 1 & 1 & 1 & 1 & & 1 & 1 & & $P$ & $P$ & SHHBM & $0-40$ \\
\hline Coregonus maraena & Maraena whitefish & 1 & 1 & 1 & 1 & & & 1 & & SHB & SHHBNM & SHHBNM & $0-15$ \\
\hline Coregonus maraena & Maraena whitefish & 1 & 1 & 1 & 1 & 1 & & 1 & & SHB & SHHBNM & SHHBNM & $0-5$ \\
\hline Coryphaenoides rupestris & Roundnose grenadier & & & 1 & & 1 & & & 1 & $P$ & $P$ & $\mathrm{P}$ & $400-1000$ \\
\hline Cottus gobio & Bullhead & 1 & 1 & & 1 & & & 1 & & SHHBNM & SHHBNM & SHHBNM & $0-6$ \\
\hline Ctenolabrus rupestris & Goldsinny wrasse & & & 1 & 1 & & & & 1 & SHHBM & SHHBM & SHHBM & $0-20$ \\
\hline Cyclopterus lumpus & Lumpfish & & 1 & 1 & 1 & 1 & & 1 & & HBNM & HBNM & DHBNM & $5-40$ \\
\hline Esox lucius & Pike & 1 & 1 & 1 & 1 & & & 1 & & SHB & SHSBM & SHSBM & $0-6$ \\
\hline Fucus radicans & Baltic bladderwrack & & 1 & & 1 & & & & & SHHBM & SHHBM & SHHBM & - \\
\hline Fucus serratus & Toothed/Serrated wrack & & 1 & 1 & 1 & & & & & SHHBM & SHHBM & SHHBM & $0-10$ \\
\hline Fucus vesiculosus & Bladderwrack & & 1 & 1 & 1 & & & & & SHHBM & SHHBM & SHHBM & $0-10$ \\
\hline Gadus morhua & Atlantic cod & & 1 & 1 & 1 & 1 & 1 & & 1 & $\mathrm{P}$ & SHSBM & $\mathrm{P}$ & $10-270$ \\
\hline Gasterosteus aculeatus & Three-spined stickleback & 1 & 1 & 1 & 1 & & 1 & 1 & & $\mathrm{P}$ & SHBM & SHHBM & $0-6$ \\
\hline Gobius niger & Black goby & 1 & 1 & 1 & 1 & & & 1 & & SHB & SHB & SHHBNM & $0-75$ \\
\hline Gymnocephalus cernua & Ruffe & 1 & 1 & & 1 & 1 & & 1 & & SHSB & - & SHHBM & $3-6$ \\
\hline Hediste diversicolor & Ragworm & & 1 & 1 & 1 & & & 1 & & DSBNM & DSBNM & DSBNM & - \\
\hline Homarus gammarus & European lobster & & & 1 & 1 & & & 1 & & DHBNM & DHBNM & DHBNM & $<40$ \\
\hline Idotea balthica & Baltic isopod & 1 & 1 & 1 & 1 & & & & & SHB & SHB & SHB & $0-34$ \\
\hline Labrus bergylta & Ballan wrasse & & & 1 & 1 & & & 1 & & SHHB & SHHB & SHHBNM & $0-30$ \\
\hline Leuciscus idus & Ide & 1 & 1 & & 1 & & & 1 & & SHB & SHSBM & SHSBM & $0-6$ \\
\hline Liparis liparis & Striped seasnail & 1 & 1 & 1 & & 1 & & 1 & & DB & DB & DHBNM & $5-300$ \\
\hline Littorina fabalis & Flat periwinkle & & & 1 & 1 & & & 1 & & SHHB & SHHBNM & SHHBNM & $0-5$ \\
\hline Littorina littorea & Common periwinkle & & & 1 & 1 & & & & 1 & SHHB & SHHBNM & SHHBNM & $0-15$ \\
\hline Littorina saxatilis & Rough periwinkle & & & 1 & 1 & & & 1 & & SHHB & SHHBNM & SHHBNM & $0-1$ \\
\hline Lophelia pertusa & Spider hazards & & & 1 & 1 & & & & & DSBNM & DSBNM & DSBNM & $80-500$ \\
\hline Lota lota & Burbot & 1 & 1 & 1 & 1 & & & 1 & & SHHB & SHHB & SHHBNM & $0.5-3$ \\
\hline Merluccius merluccius & European hake & & & 1 & & 1 & & & 1 & $\mathrm{P}$ & $P$ & $\mathrm{P}$ & $100-1000$ \\
\hline Modiolus modiolus & Northern horsemussel & & & 1 & 1 & & & & 1 & DHBNM & DHBNM & DSBNM & $20-50$ \\
\hline Mytilus edulis & Blue mussel & 1 & 1 & 1 & 1 & & & & 1 & SHHBNM & SHHBNM & SHHBNM & $0-10$ \\
\hline Nerophis ophidion & Straightnose pipefish & & & & 1 & & & & & SHSBM & SHSBM & SHSBM & $2-5$ \\
\hline Ostrea edulis & Flat oyster & & & 1 & 1 & & & & 1 & SHHBM & SHHBNM & SHHBNM & $2-10$ \\
\hline Perca fluviatilis & European perch & 1 & 1 & & 1 & & & 1 & & SHB & SHSBM & SHSBM & $0-5$ \\
\hline Pholis gunnellus & Rock gunnel & 1 & 1 & 1 & 1 & & & 1 & & SHHB & SHHB & SHHBNM & $2-6$ \\
\hline Platichthys flesus & European flounder & & 1 & 1 & 1 & 1 & & & 1 & SHB & SHSBMF & DSBNM & $0-100$ \\
\hline Platichthys solemdali & European flounder & & 1 & & 1 & 1 & & 1 & & SHB & SHSBMF & SHSBMF & $0-100$ \\
\hline Pleuronectes platessa & European plaice & & 1 & 1 & 1 & 1 & & & 1 & SHSBMF & SHSBMF & SHSBMF & $20-90$ \\
\hline
\end{tabular}


Table 1 continued

\begin{tabular}{|c|c|c|c|c|c|c|c|c|c|c|c|c|c|}
\hline \multirow[t]{2}{*}{ Species } & \multirow[t]{2}{*}{ Common name } & \multicolumn{3}{|c|}{ Distribution } & \multicolumn{3}{|c|}{ Zone } & \multicolumn{2}{|c|}{ Spawning } & \multirow[t]{2}{*}{ A habitat } & \multirow[t]{2}{*}{ J habitat } & \multirow[t]{2}{*}{ S habitat } & \multirow{2}{*}{$\begin{array}{l}\text { S depth } \\
\text { (m) }\end{array}$} \\
\hline & & G & B & KS & $\begin{array}{l}\mathrm{C} / \\
\mathrm{L}\end{array}$ & $\mathrm{B}$ & $\mathrm{P}$ & $\mathrm{D}$ & $\mathrm{P}$ & & & & \\
\hline Pomatoschistus minutus & Sand goby & 1 & 1 & 1 & 1 & & & 1 & & SHB & SHB & SHSBMF & $0-3$ \\
\hline Pygospio elegans & Polychaete & & 1 & 1 & 1 & & & & & DSBNM & DSBNM & DSBNM & - \\
\hline Ruppia maritima & Beaked tasselweed & & 1 & 1 & 1 & & & & & SHSBM & SHSBM & SHSBM & - \\
\hline Ruppia spiralis & Widgeongrass & & 1 & 1 & 1 & & & & & SHSBM & SHSBM & SHSBM & - \\
\hline Rutilus rutilus & Roach & 1 & 1 & & 1 & & & 1 & & $\mathrm{~B} / \mathrm{P}$ & $\mathrm{B} / \mathrm{P}$ & SHSBM & $0-1$ \\
\hline Salmo salar & Atlantic salmon & 1 & 1 & 1 & 1 & & 1 & 1 & & $\mathrm{P}$ & SHHBNM & SHHBNM & $0.3-3$ \\
\hline Salmo trutta & Sea trout & 1 & 1 & 1 & 1 & & 1 & 1 & & $\mathrm{P}$ & SHHBNM & SHHBNM & $0.3-1$ \\
\hline Sander lucioperca & Pike-perch & 1 & 1 & & 1 & & & 1 & & SHB & SHSBM & SHSBNM & $1-6$ \\
\hline Scomber scombrus & Atlantic mackerel & 1 & 1 & 1 & & & 1 & & 1 & $\mathrm{P}$ & $\mathrm{P}$ & $\mathrm{P}$ & $0-20$ \\
\hline Scophthalmus maximus & Turbot & & 1 & 1 & 1 & 1 & & 1 & & SHB & SHSBNM & SHSBNM & $0-20$ \\
\hline Skeletonema marioni & Diatom & 1 & 1 & 1 & & & 1 & & & $\mathrm{P}$ & $P$ & $P$ & - \\
\hline Solea solea & Common sole & & & 1 & 1 & 1 & & 1 & & SHSBMF & SHSBNM & SHSBNM & $<30$ \\
\hline Sprattus sprattus & European sprat & & 1 & 1 & 1 & & 1 & & 1 & $\mathrm{P}$ & $\mathrm{P}$ & $\mathrm{P}$ & $0-40$ \\
\hline Symphodus melops & Corkwing wrasse & & & 1 & 1 & & & 1 & & SHHB & SHHB & SHHBM & $0-30$ \\
\hline Zoarces viviparus & Eelpout & 1 & 1 & 1 & 1 & & & & & SHHB & SHHB & SHHBM & $2-20$ \\
\hline Zostera marina & Eelgrass & & 1 & 1 & 1 & & & & & SHSBM & SHSBM & SHSBM & $0-6$ \\
\hline Zostera noltii & Dwarf eelgrass & & & 1 & 1 & & & & & SHSBM & SHSBM & SHSBM & - \\
\hline
\end{tabular}

barriers are particularly apparent in the transition region between the North Sea and the Baltic Sea were salinity, depth and currents abruptly change across short distances from marine (35 psu) to brackish (10 psu) conditions (Ulrich et al. 2017), which restricts exchange of organisms between the Baltic and the North Sea (Johannesson and André 2006). This gradient continues throughout the Baltic Sea to the Bothnian Bay furthest north, where salinity conditions are as low as 2-4 psu. The effects of this environmental gradient on the connectivity of common organisms can also be seen in studies on e.g. herring (Jörgensen et al. 2005), sprat (Limborg et al. 2009), perch (Olsson et al. 2011) and whitefish (Olsson et al. 2012b), where genetic patterns in putatively neutral genetic markers differ between areas of different salinity.

Fish generally have larger home ranges than invertebrates, and juveniles generally have smaller home ranges than adults (Fig. 2). Many species, particularly large fish, migrate on a seasonal basis between shallow coastal feeding, spawning and nursery grounds in order to optimise spawning and food intake (Table 2; Aro 1989; Candolin and Voigt 2003; Tibblin et al. 2016). These areas provide optimum conditions for egg and larval development, which are more reliant on higher temperatures than adults. These habitats also provide young with sufficient food and shelter. Seitz et al. (2014) found that as much as $44 \%$ of all commercially important species in the northeast Atlantic use shallow coastal areas either as feeding, spawning or nursery areas and that these stocks make up $77 \%$ of commercial fish landings. Other species (anadromous species) like salmon (Salmo salar) and sea trout (Salmo trutta) migrate from feeding grounds in the southern part of the Baltic Sea to rivers in the Bothnian Bay where they spawn (migrating up to $1500 \mathrm{~km}$; Table 2). Although most of the species like pike, perch and various cyprinids spawn in coastal brackish waters, some populations are anadromous and return to freshwater creeks to spawn, similar to salmon and sea trout (Tibblin et al. 2012; Larsson et al. 2015). The European eel (Anguilla anguilla) preforms the most extreme spawning migration from freshwater creeks and rivers to the Sargasso Sea, several thousands of kilometres away from the Baltic Sea.

\section{GENETIC CONNECTIVITY}

Genetic connectivity is defined as "the degree to which gene flow affects evolutionary processes within subpopulations" (Lowe and Allendorf 2010). Areas are genetically connected if individuals are dispersed between populations and also contribute genetically to the next generation, i.e. successful reproduction.

Connectivity can be studied using genetic markers in two primary ways. Either indirectly by studies of population structure or directly, identifying putative migrants by inferring the population origin of specific individuals or its parents (Botsford et al. 2009; Planes et al. 2009; Gagnaire et al. 2015). The former is most common, and there are 


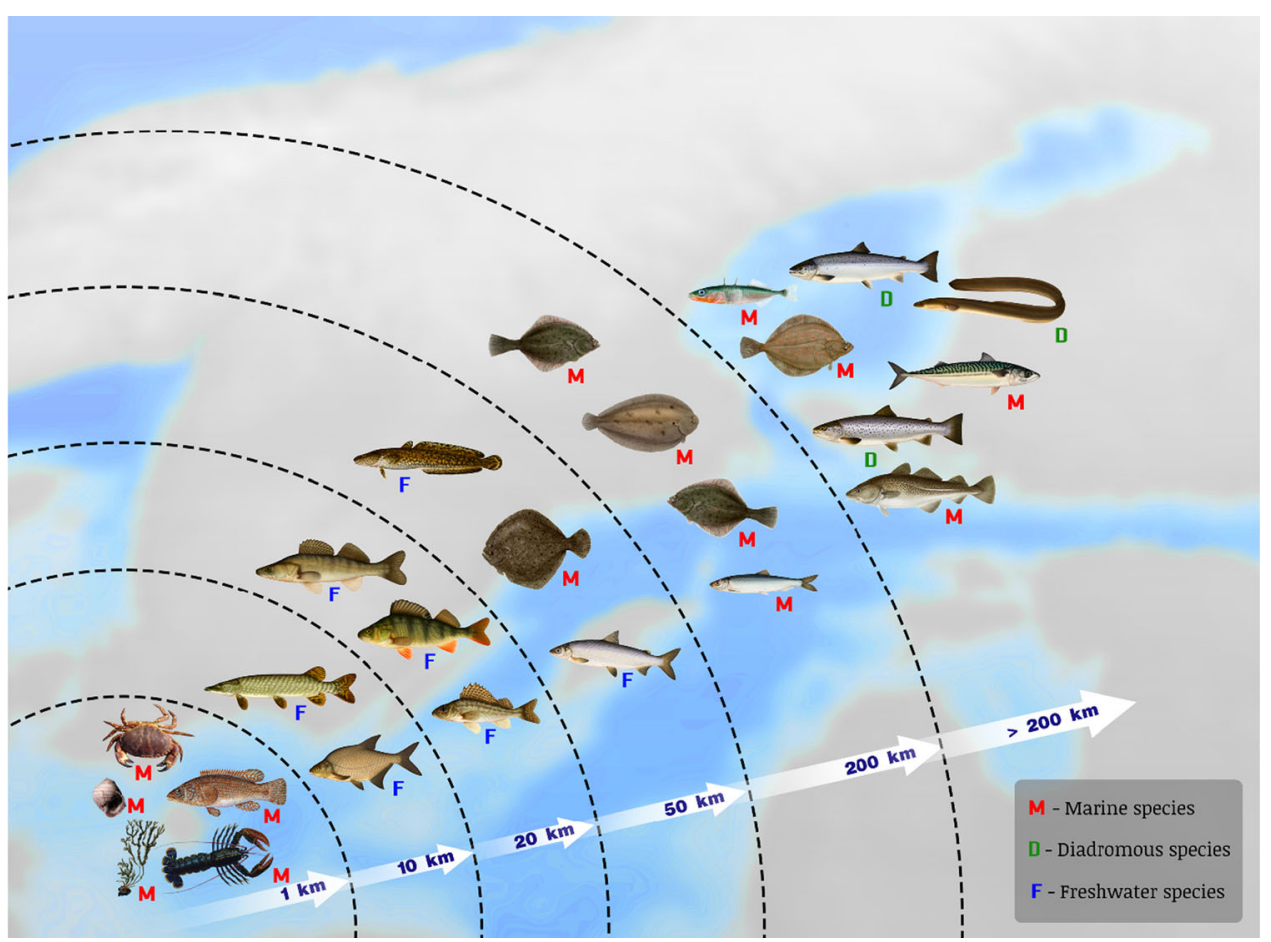

Fig. 2 Species have different home ranges based on active migrations and therefore require different sizes and placements of MPAs. MPAs often need to be larger than the species home range to protect adult individuals. The figure illustrates home ranges for some key species found in the Baltic Sea, Kattegat and Skagerrak, for which dispersal distances are known. Species in each home range category are listed from top to bottom: $<1 \mathrm{~km}$ Cancer pagurus, Littorina fabalis, Labrus bergylta, Fucus vesiculosus, Homarus gammarus; $<10 \mathrm{~km}$ Esox lucius Abramis brama; $<20 \mathrm{~km}$ Sander lucioperca, Perca fluviatilis, Gymnocephalus cernuus; $<50 \mathrm{~km}$ Zoarces viviparus, Scophthalmus maximus, Coregonus maraena (sea-spawning); $<200 \mathrm{~km}$ Platichthys flesus, Solea solea, Platichthys solemdali, Clupea harengus; > $200 \mathrm{~km}$, Salmo salar, Gasterosteus aculeatus, Anguilla anguilla, Pleuronectes platessa, Scomber scombrus, Salmo trutta and Gadus morhua. Figure adapted from Green et al. (2014). Illustrations used with permission from ArtDatabanken, Swedish University of Agricultural Sciences

many examples of studies estimating the distribution of populations and/or differentiation among populations in the Baltic Sea, Kattegat, and Skagerrak (Wennerström et al. 2017). The latter example is relatively rare worldwide. Even though genetics is a potentially powerful tool to study connectivity directly, and genetic markers can be used as individual tags, it requires rigorous sampling of target and source populations on a scale that is rarely feasible.

Genetic population range reflects the maximum distance at which populations can be considered connected genetically, either directly through dispersal and following establishment and/or reproduction or indirectly by a multigenerational stepping stone process. Genetic differentiation among populations is affected by a number of processes, such as effective population size and migration distances, while, importantly, our perception of genetic differentiation is affected by the choice of genetic markers (Kinlan and Gaines 2003). Neutral and selected genetic markers for example reflect different processes and genetic significant differences while markers under selection can show genetic differentiation even when gene flow is substantial (e.g. Han et al. 2020). In this study we use the distance at which significant genetic differences are found, regardless of genetic marker studied, as an indication of genetic population range. When compared to other measurements of dispersal, genetic population range can be divided into three groups. Species where the genetic population range is;

1. larger than other measurements of dispersal.

2. about the same as other measurements of dispersal.

3. smaller than other measurements of dispersal.

Species where the genetic population range is larger than other measurements of dispersal include macrophytes, invertebrates, and some species of coastal fish. These species have a sedentary life style with rare long distance dispersal events. In macrophytes, fragments of disconnected plant material can travel long distances (Pereyra et al. 2013). Invertebrates primarily disperse with ocean currents during a planktonic larval stage (Kinlan and Gaines 2003). For coastal fish species like pike and turbot it might be possible for some individuals to migrate over large distances (Laikre et al. 2005; Florin and Franzén 2010; Wennerström et al. 2016). These rare migration 
Table 2 Summary of dispersal and migration distances for species in the Gulf of Bothnia, Baltic Proper (including the Gulf of Finland and Riga), Kattegat and Skagerrak displayed as home range (active migrations), dispersal by fragments or larvae/spores/seeds and distributions based on genetic studies. $\mathrm{M}=$ Marine and $\mathrm{AN}=$ Anadromous. References from which distances have been extracted can be found in Table S1

\begin{tabular}{|c|c|c|c|c|c|c|}
\hline \multirow[t]{2}{*}{ Species } & \multirow[t]{2}{*}{ Common name } & \multirow{2}{*}{$\begin{array}{l}\text { Adult homerange } \\
\text { Mean }\end{array}$} & \multicolumn{2}{|c|}{ Asexual dispersal } & \multirow{2}{*}{$\begin{array}{l}\text { Larval/Propagule } \\
\text { Dispersal }\end{array}$} & \multirow{2}{*}{$\begin{array}{l}\text { Population } \\
\text { Distribution }\end{array}$} \\
\hline & & & Mean & $\operatorname{Max}$ & & \\
\hline Abramis brama & Freshwater bream & $<5 \mathrm{~km}$ & - & - & - & - \\
\hline Acipenser oxyrinchus & Atlantic Sturgeon & $<800 \mathrm{~km}$ & - & - & - & - \\
\hline Ammodytes marinus & Lesser sand-eel & - & - & - & - & $300-700 \mathrm{~km}$ \\
\hline Amphibalanus improvisus & Bay barnacle & Stationary & - & - & $160 \mathrm{~km}$ & - \\
\hline Anguilla anguilla & European eel & $>5000 \mathrm{~km}$ & - & - & - & $>1000 \mathrm{~km}$ \\
\hline Ascidia mentula & Tunicate & Stationary & - & - & $1.5 \mathrm{~km}$ & - \\
\hline Ascophyllum nodosum & Knotted wrack & Stationary & - & - & $>5 \mathrm{~m}$ & - \\
\hline Aurelia aurita & Moon jellyfish & - & - & - & $40 \mathrm{~km}$ & - \\
\hline Cancer pagurus & Edible/Brown crab & $<1 \mathrm{~km}$ & - & - & - & $>1300 \mathrm{~km}$ \\
\hline Carcinus maenas & Eruopean shore crab & - & - & - & $148-160 \mathrm{~km}$ & - \\
\hline Ciona intestinalis & Vase tunicate & - & - & - & - & $10 \mathrm{~km}$ \\
\hline Clupea harengus & Atlantic herring & $150 \mathrm{~km}$ & - & - & - & $400-1000 \mathrm{~km}$ \\
\hline Coregonus maraena & Maraena whitefish (M) & $20-40 \mathrm{~km}$ & - & - & - & $100 \mathrm{~km}$ \\
\hline Coregonus maraena & Maraena whitefish (AN) & $300-500 \mathrm{~km}$ & - & - & - & - \\
\hline Coryphaenoides rupestris & Roundnose grenadier & - & - & - & - & $100 \mathrm{~km}$ \\
\hline Cottus gobio & Bullhead & - & - & - & $160 \mathrm{~km}$ & - \\
\hline Ctenolabrus rupestris & Goldsinny wrasse & $100 \mathrm{~m}$ & - & - & - & - \\
\hline Cyclopterus lumpus & Lumpfish & - & - & - & - & $1000 \mathrm{~km}$ \\
\hline Esox lucius & Pike & $3 \mathrm{~km}$ & - & - & - & $10-400 \mathrm{~km}$ \\
\hline Fucus radicans & Baltic bladderwrack & Stationary & $10 \mathrm{~m}-1 \mathrm{~km}$ & $>100 \mathrm{~km}$ & $1-2 \mathrm{~m}$ & $550 \mathrm{~km}$ \\
\hline Fucus serratus & Toothed/Serrated wrack & Stationary & - & - & $1-2 \mathrm{~m}$ & $2 \mathrm{~km}$ \\
\hline Fucus vesiculosus & Bladderwrack & Stationary & $10 \mathrm{~m}-1 \mathrm{~km}$ & $250 \mathrm{~km}$ & $1-2 \mathrm{~m}$ & $10 \mathrm{~m}-500 \mathrm{~km}$ \\
\hline Gadus morhua & Atlantic cod & $100-800 \mathrm{~km}$ & - & - & $600 \mathrm{~km}$ & $100-400 \mathrm{~km}$ \\
\hline Gasterosteus aculeatus & Three-spined stickleback & $>100 \mathrm{~km}$ & - & - & - & $200-1000 \mathrm{~km}$ \\
\hline Gobius niger & Black goby & - & - & - & $160 \mathrm{~km}$ & - \\
\hline Gymnocephalus cernua & Ruffe & $<15 \mathrm{~km}$ & - & - & - & - \\
\hline Hediste diversicolor & Ragworm & - & - & - & Few meters & - \\
\hline Homarus gammarus & European lobster & $<250 \mathrm{~m}$ & - & - & - & $>400 \mathrm{~km}$ \\
\hline Idotea balthica & Baltic isopod & - & - & - & - & $100-300 \mathrm{~km}$ \\
\hline Labrus bergylta & Ballan wrasse & $100 \mathrm{~m}$ & - & - & - & - \\
\hline Leuciscus idus & Ide & - & - & - & - & - \\
\hline Liparis liparis & Striped seasnail & - & - & - & $55 \mathrm{~km}$ & - \\
\hline Littorina fabalis & Flat periwinkle & $2 \mathrm{~m}$ & - & - & - & - \\
\hline Littorina littorea & Common periwinkle & - & - & - & $300 \mathrm{~km}$ & - \\
\hline Littorina saxatilis & Rough periwinkle & $2 \mathrm{~m}$ & - & - & - & $1-2 \mathrm{~km}$ \\
\hline Lophelia pertusa & Spider hazards & - & - & - & $40 \mathrm{~km}$ & $<35 \mathrm{~km}$ \\
\hline Lota lota & Burbot & $20 \mathrm{~km}$ & - & - & - & - \\
\hline Merluccius merluccius & European hake & - & - & - & - & $700 \mathrm{~km}$ \\
\hline Modiolus modiolus & Northern horsemussel & Stationary & - & - & $10 \mathrm{~km}$ & - \\
\hline Mytilus edulis & Blue mussel & Stationary & - & - & $10-50 \mathrm{~km}$ & $300-600 \mathrm{~km}$ \\
\hline Nerophis ophidion & Straightnose pipefish & - & - & - & $160 \mathrm{~km}$ & - \\
\hline Ostrea edulis & Flat oyster & Stationary & - & - & $88 \mathrm{~km}$ & - \\
\hline Perca fluviatilis & European perch & $10 \mathrm{~km}$ & - & - & $0.1-2 \mathrm{~km}$ & $2-100 \mathrm{~km}$ \\
\hline Pholis gunnellus & Rock gunnel & - & - & - & $84 \mathrm{~km}$ & - \\
\hline Platichthys flesus & European flounder & $30-200 \mathrm{~km}$ & - & - & $300 \mathrm{~km}$ & $300-600 \mathrm{~km}$ \\
\hline Platichthys solemdali & European flounder & $30-200 \mathrm{~km}$ & - & - & - & $300-400 \mathrm{~km}$ \\
\hline
\end{tabular}


Table 2 continued

\begin{tabular}{|c|c|c|c|c|c|c|}
\hline \multirow[t]{2}{*}{ Species } & \multirow[t]{2}{*}{ Common name } & \multirow{2}{*}{$\begin{array}{l}\text { Adult homerange } \\
\text { Mean }\end{array}$} & \multicolumn{2}{|c|}{ Asexual dispersal } & \multirow{2}{*}{$\begin{array}{l}\text { Larval/Propagule } \\
\text { Dispersal }\end{array}$} & \multirow{2}{*}{$\begin{array}{l}\text { Population } \\
\text { Distribution }\end{array}$} \\
\hline & & & Mean & $\operatorname{Max}$ & & \\
\hline Pleuronectes platessa & European plaice & $300-500 \mathrm{~km}$ & - & - & - & $200 \mathrm{~km}$ \\
\hline Pomatoschistus minutus & Sand goby & - & - & - & $160 \mathrm{~km}$ & $700 \mathrm{~km}$ \\
\hline Pygospio elegans & Polychaete & - & - & - & $87 \mathrm{~km}$ & - \\
\hline Ruppia maritima & Beaked tasselweed & Stationary & - & - & - & $4 \mathrm{~m}-20 \mathrm{~km}$ \\
\hline Ruppia spiralis & Widgeongrass & Stationary & $5-20 \mathrm{~km}$ & $179 \mathrm{~km}$ & - & $20 \mathrm{~km}$ \\
\hline Rutilus rutilus & Roach & $5 \mathrm{~km}$ & - & - & - & - \\
\hline Salmo salar & Atlantic salmon & $100-1000 \mathrm{~km}$ & - & - & - & $50-200 \mathrm{~km}$ \\
\hline Salmo trutta & Sea trout & $100-300 \mathrm{~km}$ & - & - & - & $100-200 \mathrm{~km}$ \\
\hline Sander lucioperca & Pike-perch & $10 \mathrm{~km}$ & - & - & - & $50-200 \mathrm{~km}$ \\
\hline Scomber scombrus & Atlantic mackerel & $500 \mathrm{~km}$ & - & - & - & - \\
\hline Scophthalmus maximus & Turbot & $10-30 \mathrm{~km}$ & - & - & $200 \mathrm{~km}$ & $400-1000 \mathrm{~km}$ \\
\hline Skeletonema marioni & Diatom & - & - & - & - & $20-150 \mathrm{~km}$ \\
\hline Solea solea & Common sole & $150 \mathrm{~km}$ & - & - & - & $350-400 \mathrm{~km}$ \\
\hline Sprattus sprattus & European sprat & - & - & - & - & $150-400 \mathrm{~km}$ \\
\hline Symphodus melops & Corkwing wrasse & $100 \mathrm{~m}$ & - & - & - & $60-700 \mathrm{~km}$ \\
\hline Zoarces viviparus & Eelpout & - & - & - & - & $50-500 \mathrm{~km}$ \\
\hline Zostera marina & Eelgrass & Stationary & $10-100 \mathrm{~km}$ & $150-200$ km & $5 \mathrm{~m}$ & $300 \mathrm{~km}$ \\
\hline Zostera noltii & Dwarf eelgrass & Stationary & - & - & - & $65-150 \mathrm{~km}$ \\
\hline
\end{tabular}

events do not affect ecological connectivity and population dynamics greatly, but might have a large impact on genetic patterns.

The second group, where genetic population range and other dispersal measurements are roughly the same, includes marine species like cod, herring, sprat and threespined stickleback. These species have large population sizes and few barriers to migration, which is reflected in genetic patterns where differences among populations typically are small. Also species with clonal dispersal, such as Fucus radicans, have matching ranges of different dispersal measurements.

There are also a number of species where the genetic population range is smaller than other measurements of individual movement. Species with a strong homing behaviour, like salmon and trout belong to this group. These species typically have unique spawning populations in individual streams, or even multiple populations within streams (Koljonen et al. 2002; Vasemägi et al. 2005). During feeding, however, they can migrate hundreds of kilometres. For species like salmon, sea trout and pike, however, it may be a disadvantage to solely use genetic methods to study connectivity since many individuals are farmed and released for conservation purposes. Genetic variation will not always reflect natural dispersal in those cases.

\section{INCORPORATING CONNECTIVITY IN MANAGEMENT AND MARINE PROTECTED AREA NETWORK DESIGN}

When designing and implementing MPAs it is important to acknowledge the different types of connectivity including active migrations and passive dispersal as well as the movements and needs of different life-stages (FélixHackradt et al. 2018). It is also important to separate between typical home ranges and maximum migration distances since home ranges reflect scales relevant for population dynamics while maximum distances are more important for the genetic variation between populations (Bergström et al. 2007). An MPA may either be larger than an organisms' dispersal range in order to keep a viable population within the MPA or consist of a network of MPAs placed with distances equivalent to organisms' dispersal ranges in order to connect populations within the network (Carr et al. 2017). Additionally, it should include all habitats needed during an organism's lifecycle (spawning, nursery and feeding) to make sure the MPA network is ecologically coherent, unless these habitats are found in adequate condition outside the MPA network and within the organism's dispersal range. Connectivity within MPAs is hence important for species with short dispersal ranges and found in fragmented habitats, while connectivity between MPAs and the surrounding area is important 
for dispersal and genetic exchange between populations across larger areas (Andersson et al. 2008).

Understanding dispersal patterns between MPAs is complex due to dispersal being dictated by currents, time of year, amount of time larvae/spores spend in the pelagic and at what depth they are located (Kinlan and Gaines 2003). How far larvae/spores disperse is determined by how long they remain viable in the water column and what environmental conditions they are subjected to. Larvae can partly regulate their dispersal by shifting between water layers and hence choose which currents to disperse with (Moksnes et al. 2014a). Larvae with long larval durations that spend time close to the surface generally disperse further than larvae with short larval durations that spend time at deeper depths $(>20 \mathrm{~m})$ since surface currents often are faster than currents below the thermocline (Moksnes et al. 2014b). Sea star- and cod larvae are examples of organisms dispersing far in surface waters while mussels and gastropods often spend time below the thermocline and therefore have more limited dispersal (Moksnes et al. 2014b). Although some larvae have long larval durations, their dispersal may be limited by local water currents such as eddies that retain larvae within a bay or fjord (Cowen et al. 2000; Øresland and Ulmestrand 2013). Local hydrodynamic conditions are therefore equally important to consider in MPA design as is large scale climate and hydrological conditions. In fact, otolith and genetic studies have found that pelagic larvae have more limited dispersals than previously thought, often within 10-100 km (Palumbi 2004; Cowen et al. 2006; Benestan et al. 2021). Fish larvae and larvae of larger decapods like spiny lobster (Palinuridae) may also actively swim against currents in their last stages of development before settling and partly affect dispersal (Fisher 2005; Leis 2006). For instance, Faillettaz et al. (2018) found that fish larvae behaviour affected the dispersal among MPAs in the Mediterranean.

Considering the large environmental changes in the Baltic Sea and the mix of marine and freshwater species, environmental variables including salinity, temperature, oxygen levels and currents will limit dispersal and hence need to be taken into account when deciding on sizes, numbers and placement of MPAs. This poses extra challenges when managing the Baltic Sea area. If MPA design is developed based on species and habitat maps, many of these environmental variables will automatically be incorporated since the variables dictate species ranges. Furthermore, local adaptations particularly prominent in the two endemic species, Baltic flounder Platichthys solemdali and the brown algae Fucus radicans, result in contrasting dispersal and connectivity patterns in the two different organismal groups (Momigliano et al. 2018). The Baltic flounder has developed heavier eggs, different larval behaviour and spawn in coastal areas allowing shorter dispersal compared to its closest relative European flounder (Nissling et al. 2017; Corell and Nissling 2019). In contrast, $F$. radicans relies on asexual reproduction and disperses farther than its closest relative bladderwrack, and therefore has a more northern distribution in the Bothnian Sea where the population is represented by one dominant clone (Bergström et al. 2005; Tatarenkov et al. 2005; Ardehed et al. 2015).

The northern parts of the Gotland basin, with low oxygen levels, is considered a barrier for adult European flounder, restricting their migration northwards across these unfavourable areas. Their pelagic larvae, on the other hand, may disperse across this hypoxic/anoxic zone (Aro 1989; Florin and Höglund 2008). Furthermore, European flounder and cod need areas with high salinity and oxygen levels for egg and larval survival and are therefore limited to spawn in isolated deep water basins with suitable conditions, such as the Bornholm Basin, the Gdansk Deep, and the Gotland Basin. Limited spawning due to unfavourable oxygen conditions in the Gotland basin may explain the large declines in catches of European flounder close to its geographical boarder in the Gulf of Finland (GoF) since the mid-1980s (Jokinen et al. 2019). Similarly, the spatial contraction of the eastern Baltic cod population to the Bornholm basin has been suggested to be a consequence of a loss of suitable spawning habitat in the Gotland Basin (Bartolino et al. 2017).

Mobility of species differ between species of marine or freshwater origin. Large stretches of deep water may therefore function as barriers for coastal species of freshwater origin (e.g. perch) which are relatively stationary and have short larval dispersal (Olsson et al. 2011). This strategy of a more direct development may be beneficial for species living close to their environmental limits. The proportion of freshwater and marine species also varies between water basins, e.g. freshwater and anadromous species with low dispersal dominate in the Bothnian Bay while marine species with pelagic larval phases and larger dispersal ranges dominate towards the North Sea.

\section{CONSIDERING CLIMATE CHANGE AND OTHER ANTHROPOGENIC DISTURBANCES}

An MPA network should ideally withstand local and global disturbances from climate change and other anthropogenic pressures. Including connectivity in MPA design may be even more crucial in the light of climate change because dispersal of organisms between areas will facilitate both survival and recovery of populations (Magris et al. 2014; Balbar and Metaxas 2019). Dispersal and distribution ranges of species may, however, be negatively affected by climate change due to changes in temperature, salinity and 
Table 3 Summary of studies evaluating ecological coherence of MPA networks in the Baltic Sea, Kattegat and Skagerrak

\begin{tabular}{|c|c|c|c|c|c|c|c|}
\hline Geografical area & Year & Organism & Species & Type av connectivity & References & Publication & Resultats \\
\hline Baltic Sea & 2007 & $\begin{array}{c}\text { Macrophytes/ } \\
\text { Macroalgae/ } \\
\text { Inverts/Fish }\end{array}$ & 5 key organisms & Larval disp + nursery gounds & $\begin{array}{l}\text { Piekäinen and } \\
\text { Korpinen } \\
(2007)\end{array}$ & Report & $\begin{array}{l}\text { Partly } \\
\quad \text { coherent }\end{array}$ \\
\hline Baltic Sea & 2007 & Fish & Herring & Spawning + nursery grounds & $\begin{array}{l}\text { Bergström et al. } \\
\text { (2007) }\end{array}$ & Report & $\begin{array}{l}\text { Partly } \\
\quad \text { coherent }\end{array}$ \\
\hline Baltic Sea & 2010 & $\begin{array}{c}\text { Macrophytes/ } \\
\text { Macroalgae/ } \\
\text { Inverts/Fish }\end{array}$ & 5 key organisms & Larval disp + nursery gounds & HELCOM (2010) & Report & $\begin{array}{l}\text { Partly } \\
\quad \text { coherent }\end{array}$ \\
\hline Baltic Sea & 2011 & Fish & $\begin{array}{l}\text { Pike, Perch, Pike- } \\
\text { perch, Roach }\end{array}$ & Nursery grounds & $\begin{array}{l}\text { Sundblad et al. } \\
\quad(2011)\end{array}$ & Article & $\begin{array}{l}\text { Not } \\
\quad \text { coherent }\end{array}$ \\
\hline Baltic Sea & 2012 & Inverts/Fish & Several & Larval disp & Corell et al. (2012) & Article & $\begin{array}{l}\text { Not } \\
\quad \text { coherent }\end{array}$ \\
\hline Baltic Sea & 2012 & Inverts & Blue mussel & Larval disp & $\begin{array}{l}\text { Nilsson Jacobi } \\
\text { et al. (2012) }\end{array}$ & Article & $\begin{array}{l}\text { Not } \\
\quad \text { coherent }\end{array}$ \\
\hline Baltic Sea & 2015 & - & - & Larval disp & $\begin{array}{l}\text { Wolters et al. } \\
\text { (2015) }\end{array}$ & Report & $\begin{array}{l}\text { Not } \\
\quad \text { coherent }\end{array}$ \\
\hline Baltic Sea & 2017 & $\begin{array}{c}\text { Macrophytes/ } \\
\text { Macroalgae/ } \\
\text { Inverts/Fish }\end{array}$ & 5 key organisms & Larval disp + nursery gounds & HELCOM (2016) & Report & $\begin{array}{l}\text { Not } \\
\quad \text { coherent }\end{array}$ \\
\hline Baltic Sea & 2018 & $\begin{array}{c}\text { Macrophytes/ } \\
\text { Macroalgae/ } \\
\text { Inverts/Fish }\end{array}$ & Several & $\begin{array}{l}\text { Distribution maps/distance-based } \\
\text { connectivity (all life-stages) }\end{array}$ & $\begin{array}{l}\text { Virtanen et al. } \\
\text { (2018) }\end{array}$ & Article & $\begin{array}{l}\text { Not } \\
\quad \text { coherent }\end{array}$ \\
\hline Baltic Sea & 2019 & Inverts/Fish & Several & Larval disp & $\begin{array}{l}\text { Jonsson et al. } \\
\quad(2020)\end{array}$ & Article & $\begin{array}{l}\text { Not } \\
\quad \text { coherent }\end{array}$ \\
\hline $\begin{array}{l}\text { Baltic Sea/ } \\
\text { Kattegatt/ } \\
\text { Skagerrak }\end{array}$ & 2021 & $\begin{array}{c}\text { Macrophytes/ } \\
\text { Macroalgae/ } \\
\text { Inverts/Fish }\end{array}$ & Several & Larval disp & Assis et al. (2021) & Article & $\begin{array}{l}\text { Not } \\
\text { coherent }\end{array}$ \\
\hline $\begin{array}{l}\text { Kattegatt/ } \\
\text { Skagerrak }\end{array}$ & $\begin{array}{l}2013 / \\
2014\end{array}$ & $\begin{array}{c}\text { Macrophytes/ } \\
\text { Macroalgae/ } \\
\text { Inverts/Fish }\end{array}$ & Several & Larval/seed disp + nursery gounds & $\begin{array}{l}\text { Johnson et al. } \\
\qquad(2013,2014)\end{array}$ & Report + Article & $\begin{array}{l}\text { Not } \\
\quad \text { coherent }\end{array}$ \\
\hline $\begin{array}{l}\text { Kattegatt/ } \\
\text { Skagerrak }\end{array}$ & 2014 & Inverts/Fish & $\begin{array}{l}45 \text { fish }+80 \\
\text { inverts }\end{array}$ & Larval disp & $\begin{array}{l}\text { Moksnes et al. } \\
(2014 \mathrm{~b}, \mathrm{a})\end{array}$ & Report & $\begin{array}{l}\text { Not } \\
\text { coherent }\end{array}$ \\
\hline $\begin{array}{l}\text { Kattegatt/ } \\
\text { Skagerrak }\end{array}$ & 2015 & Inverts/Fish & Several & Larval disp & $\begin{array}{l}\text { Moksnes et al. } \\
\text { (2015) }\end{array}$ & Report & $\begin{array}{l}\text { Not } \\
\text { coherent }\end{array}$ \\
\hline $\begin{array}{l}\text { Kattegatt/ } \\
\text { Skagerrak }\end{array}$ & 2016 & Inverts/Fish & Several & Larval disp & $\begin{array}{r}\text { Jonsson et al. } \\
(2016 \mathrm{a}, \mathrm{b})\end{array}$ & Article & $\begin{array}{l}\text { Not } \\
\quad \text { coherent }\end{array}$ \\
\hline
\end{tabular}

water movement (Bruno et al. 2018). Changes in dispersal between MPAs may in turn decrease the network's ability to withstand environmental changes. When planning additional MPAs it is therefore important to consider their impact on connectivity, and make sure they are placed in locations that will strengthen the connectivity of the network and increase its resilience against future changes (Carr et al. 2017). An MPA network with sufficient connectivity may also allow the range shift of locally adapted genotypes to move with climate change. Wilson et al. (2020) identified a number of climate change adaptation strategies for MPAs including increased resilience, connectivity and heterogeneity, protection of climate refugia and future habitat, reduction of other stressors and increasing adaptive capacity. Additionally, they found that $82 \%$ of real-world examples of climate change adaptation in MPA planning derives from tropical reefs, highlighting the need for addressing temperate ecosystems. In Sweden, climate change effects on species distributions are considered in marine spatial planning, and climate refuges for some important species have been mapped in the Baltic Sea (Hammar and Mattson 2017).

Climate change in coastal and pelagic areas is already apparent in the Baltic Sea, Kattegat and Skagerrak with increasing temperatures, shorter ice periods and extended bottoms with hypoxic conditions (Viitasalo 2019). These changes affect species distribution ranges, spawning behaviour and habitat selection and may have both negative and positive effects on populations (Härmä et al. 2008; Olsson et al. 2012a; Nissling and Wallin 2020). For example, the distribution range of cod is moving north on a global scale with increasing temperatures (Werner et al. 2016), while bladderwrack's distribution range is decreasing in the Baltic Sea following a decrease in salinity and 
increase in acidity (Jonsson et al. 2018). The disappearance of canopy-forming vegetation, like bladderwrack, on hard substrates is problematic since there are no freshwater plants or algae that can replace the function of this keystone species. The observed decrease in salinity is due to an increase in precipitation and terrestrial runoff. Consequently, the freshwater gradient moves southwards in the Baltic Sea (Wake 2012). Species of freshwater origin may benefit from increased precipitation and a decrease in salinity due to an expansion of spawning and nursery areas in coastal areas (Härmä et al. 2008). Moreover, the shorter winters and higher water temperatures will in turn increase growth rates of species adapted to warm water conditions, e.g. perch, while species adapted to spawning in cold water, like whitefish (Coregonus maraena), may instead fail (Veneranta et al. 2013). Also, many coastal spawning and nursery areas will dry out earlier since the increase of water flow takes place earlier on in the season than usual (Larsson et al. 2015). Besides a decrease in salinity, the increase of anoxic conditions due to both temperature increases and eutrophication in the Baltic Sea may have large effects on marine species, like European flounder and cod, which possess larvae that are highly dependent on areas with high salinity and oxygen conditions (Orio et al. 2017, 2019). This increase of bottoms with hypoxic conditions and decrease of spawning grounds will in turn have consequences on dispersal and geographical range. Similarly, habitat shrinkage due to increased temperatures has been observed for cod around Denmark resulting in increased fragmentation and decreased connectivity of viable habitats (Dinesen et al. 2019). Hypoxic or anoxic conditions may also occur in coastal areas with increased temperatures affecting spawning and nursery areas for a number of species (Viitasalo 2019).

Due to many species living close to their physiological salinity limits, most species in the Baltic Sea will be affected and some species may even disappear. Climate effects on populations have also been observed in Kattegat, where Arctic-Boreal species have decreased in abundance and species range while Mediterranean-Boreal species have increased in abundance and species range (Göransson 2017). Arctic-Boreal species also tend to have shorter dispersal ranges than Mediterranean-Boreal species making it more difficult for these species to recolonise areas where abundances have decreased. Additionally, an increase in ocean temperature may decrease planktonic larval duration and hence dispersal distance, justifying the need for larger and closer MPAs within the network in this region (Álvarez-Romero et al. 2018).

Higher temperatures together with eutrophication and overfishing of top predators increase macroalgal blooms, both as drifting algal mats and as epiphytes on large canopy-forming macrophytes and macroalgae like eelgrass and bladderwrack (Cossellu and Nordberg 2010). These canopy forming macrophytes and algae are important spawning and nursery areas for many fish species and might disappear due to macrophytes and macroalgae being smothered and/or shaded by epiphytes (Rönnbäck et al. 2007). The lack of top predators and hence top-down control in Baltic Sea coastal areas has resulted in trophic cascades with an increase of mesopredators like the threespined stickleback, a reduction in important grazers (stickleback prey) and in increase in epiphytic algae (Donadi et al. 2017; Eklöf et al. 2020). Drifting mats of filamentous algae may also cover large areas of sandy bottoms and limit the amount of nursery area for commercially important flatfish (Pihl et al. 2005). If these key habitats disappear, connectivity by species reliant on these habitats may decrease or cease with negative effects on population dynamics.

Physical disturbance from jetties, dredging and boat traffic can have negative effects on nursery grounds (Macura et al. 2019). Many shallow protected bays with a high density of jetties and intense boat traffic have 40-80\% less vegetation than bays with few jetties in the Baltic Sea (Hansen et al. 2018). Also, the diversity of macrophytes are negatively affected by jetties and boat traffic with sensitive species often disappearing (Eriksson et al. 2004; Sandström et al. 2005). These shallow nursery areas are rather rare within the Baltic Sea seascape and are highly sensitive to disturbances (Snickars et al. 2010). Studies have shown a positive relationship between the amount of benthic vegetation and pike, perch and cyprinid larvae in areas where such macrophyte and macroalgal habitats are generally rare (Sundblad and Bergström 2014; Hansen et al. 2018). Negative effects of jetties on eelgrass meadows, also important nursery grounds (Staveley et al. 2016; Perry et al. 2018), was found in Skagerrak and Kattegat (Eriander et al. 2017). To alleviate the effects of physical disturbance and habitat loss, attempts to identify and restore important nursery areas such as coastal wetlands and seagrass beds have been made as a mean to decrease fragmentation and increase connectivity (Nilsson et al. 2014; Eriander et al. 2016; Jahnke et al. 2018, 2020).

\section{ECOLOGICAL COHERENCE OF THE MARINE PROTECTED AREA NETWORK}

In total, fifteen studies have evaluated aspects of ecological coherence of the MPA network in the Baltic Sea (10 studies), Kattegat-Skagerrak (4 studies) and both regions (1 study). The first two studies were conducted in the Baltic Sea in 2007 (Bergström et al. 2007; Piekäinen and Korpinen 2007) and the first evaluation in Kattegat-Skagerrak in 2013 (Johnson et al. 2013). Most studies found that the 
network of MPAs was non-coherent (Table 3). In some cases the network fulfilled one of the four coherence criteria (adequacy, representativity, replication, and connectivity), but far from all criteria. In general the criterion on how well connected the MPA network is, was evaluated. Focus was mainly on larval dispersal using hydrodynamic models, with three studies in Kattegat-Skagerrak (Moksnes et al. 2014b, 2015; Jonsson et al. 2016b), three in the Baltic Sea (Corell et al. 2012; Nilsson Jacobi et al. 2012; Jonsson et al. 2020) and one in both regions (Assis et al. 2021). The models were parameterised using data on drift depths and seasonal recruitment from plankton surveys. Larval dispersal was simulated by releasing virtual larvae with various swimming abilities from areas corresponding to natural distributions. The models provided useful estimates of larval dispersal for coarse-scale analyses. However, the large-scale hydrodynamic models do not account for local conditions in topographically complex areas like archipelagos. This may overestimate the dispersal of some species in coastal regions. Additionally, the models do not account for habitat differences between areas due to lack of comprehensive habitat maps of the Baltic Sea and Kattegat-Skagerrak. Results from these studies still indicate that the network of Natura 2000 areas (Corell et al. 2012; Nilsson Jacobi et al. 2012) and HELCOM MPAs (Jonsson et al. 2020) are non-coherent in the Baltic Sea and that the network is particularly weak along the Swedish east coast and the Finnish west coast. Additionally, the Swedish MPAs are generally too small for larvae spawned within MPAs to be retained and contribute to viable populations within these areas (Jonsson et al. 2020). The OSPAR MPA network was also found to be non-coherent in KattegatSkagerrak. The protected areas in the south of Kattegat and Danish Belt are the most important MPAs with regard to maintaining larval connectivity along the Swedish coastline due to surface currents mainly heading north (Moksnes et al. 2014b; Jonsson et al. 2016b), but MPAs are too small and inaccurately placed in order to maintain sufficient connectivity.

The MPA network has also been evaluated using set dispersal distances and benthic habitat maps. In the Baltic Sea this was done using set dispersal values of 25 and/or $50 \mathrm{~km}$ for a set of representative species, including bladderwrack Fucus vesiculosus, the red algae Furcellaria lumbricalis, Baltic tellin Macoma baltica, the isopod Idotea baltica and turbot Psetta maxima (Piekäinen and Korpinen 2007; HELCOM 2010, 2016; Wolters et al. 2015). The number of links (connectivity) between MPAs based on these distances and some species-specific values for the five selected species ranging from $1-100 \mathrm{~km}$, depending on species, were examined. These studies also evaluated the other three coherence criteria by studying the size distribution of MPAs (Adequacy), the amount of habitats protected (Representativity) and how many areas of at least 24 ha of each habitat that were protected (Replication). In Kattegat-Skagerrak, one study was performed, where 50 and $80 \mathrm{~km}$ were used as set dispersal values for evaluating connectivity (Johnson et al. 2014) and the other three criteria were evaluated in a similar manner as those in the Baltic Sea. Results showed that the MPA network was only partly coherent (Table 3 ).

Using similar methods, but based on species-specific habitat requirements, species distributions and active migrations, Sundblad et al. (2011) evaluated the coherence of the Natura 2000 network in a $30000-\mathrm{km}^{2}$ archipelago in the Baltic Sea. Focus was to test connectivity and representativity, defined as amount of fish habitat protected by the network, for pike (Esox lucius), perch (Perca fluviatilis), pike-perch (Sander lucioperca) and roach (Rutilus rutilus). Both connectivity of all habitats and protected habitats were evaluated. Connectivity and representativity was found to be weak, and the map-based analyses identified areas in which the network could be strengthened. This method is particularly appropriate in complex coastal areas like archipelagos, lacking high resolution hydrodynamic maps, with patchy habitat distribution and where the dispersal is mainly through active migrations by individuals.

A study evaluating representativity of herring (Clupea harengus) spawning grounds within the Natura 2000 network along the Finnish coast was also performed by Bergström et al. (2007). Representativity was high in the Bothnian Bay where $40-50 \%$ of herring spawning grounds were protected, but coherence in terms of representativity was weak in the Gulf of Finland. Recently a more thorough evaluation was performed along the Finnish coast in which distribution maps for the most common species, key species and habitat forming species (e.g. pondweed Potamogeton perfoliatus bladderwrack $F$. vesiculosus, eelgrass Z. marina and blue mussels Mytilus edulis), threatened and red listed species were included (Virtanen et al. 2018). Maps of fish nursery grounds based on models by Kallasvuo et al. (2016) were also included. Only $27 \%$ of the most ecologically important areas were found to be protected by the existing MPA network. However, by expanding the network in appropriate areas, an expansion of as little as $1 \%$ of the network would double the coherence of ecologically important areas.

Besides uncertainties regarding species dispersal ranges, one main shortcoming in all analyses was that none but Virtanen et al. (2018) had taken threats and impacts into account. Virtanen et al. (2018) included threats like habitat loss, degradation and/or disturbance of habitats, in order to identify the ecologically most important (pristine) areas. All other analyses have assumed that habitats and organisms within MPAs are highly protected. In reality, 
protection may be rather low in many areas. Fishing regulations are for example rare. Fishing might, however, have negative effects on both fish abundances, bycatch species and benthic environments subjected to destructive fishing gears (Hammersland and Hjerpe Olausson 2011). Protected areas may also be subjected to pressure from coastal development, even in cases when conservation values are impacted. For example, Eriander et al. (2017) found that the existence of an MPA only marginally reduced the approval of applications for dock constructions in threatened eelgrass habitats on the Swedish west coast. This highlights the need to consider both threats, impacts and type of protection (nature reserve, national park, Natura 2000, HELCOM, OSPAR etc.) when evaluating the MPA network.

Outside of our study region, few studies testing the ecological coherence of MPA networks exist and most of them focus on connectivity and larval dispersal (e.g. Ross et al. 2017; Assis et al. 2021). A number of studies do, however, investigate the effect of connectivity on MPAs performance, mainly in tropical regions (e.g. Ortodossi et al. 2019; Steneck et al. 2009; Goetze et al. 2021) or incorporate connectivity in conservation prioritisation by identifying and studying connectivity between nursery and adult habitats in tropical seascapes (e.g. Weeks 2017). One major difference, and challenge, between our study area and other temperate or tropical seascapes are the strong environmental gradients resulting in a great mix of both marine and freshwater species with contrasting dispersal and migration strategies and patterns. Also, habitat patches are not always as distinct as e.g. coral reefs and seagrass beds in the tropics, where connectivity between juvenile and adult habitat can more easily be assessed. Recently a study by Rees et al. (2018) suggested ways to align the process of designating ecologically coherent MPA networks with economic development, environmental sustainability and social inclusion to achieve social-ecological coherence in MPA network design. This illustrates the need to also incorporate social aspects in MPA management and governance.

\section{KNOWLEDGE NEEDS FOR IMPROVED CONNECTIVITY ANALYSES}

Knowledge on species dispersal, both active and passive, in the Baltic Sea, Kattegat and Skagerrak is limited. Tagging studies have mainly been conducted among commercially important species in order to obtain distances of active migrations (Aro 2002; Saulamo and Neuman 2002; Drenner et al. 2012). Most tagging studies have been conducted on large fish, while information on migrations by invertebrates and small, non-commercial species of fish is scarce, although these species may be important for ecosystem functioning.

Information on passive dispersal and important areas to protect has mainly been obtained from modelling studies (Corell et al. 2012; Moksnes et al. 2015; Jonsson et al. 2016b, 2020). Modelling studies have also been done separately for herring, cod, sprat, European flounder and turbot in order to identify pathways of larval dispersal and nursery grounds (Florin et al. 2013; Hinrichsen et al. 2012a, b, 2017a, b).

The number of genetic studies reflecting dispersal or migration distances are also limited. Few studies presented distance estimate values and in many cases we had to extract the information from published maps. Genetic studies displaying genetic variation among populations gave an estimate of how far individuals may disperse. However, these studies focused on the individuals that disperse/migrate the furthest, since low levels of gene flow can even out genetic differences. Tagging studies that focus on dispersal distances performed by the majority of the population reflect scales relevant to population dynamics and may hence be more useful for evaluating ecological coherence of MPAs. Combining genetic studies with other methods, such as tagging and modelling, will provide a more comprehensive overview of connectivity. However, only very few studies exist for the Baltic Sea, i.e. De Wit et al. (2020) combining genetics with a biophysical model of connectivity for the isopod Idotea balthica, Östergren et al. (2012) combining genetics with acoustic tagging to follow spawning migrations of sea trout and Larsson et al. (2015) combining genetics with otolith chemistry to track pike migration in the Baltic Sea. In Kattegat-Skagerrak, a limited amount of studies have combined genetics with larval dispersal models in cod (Jonsson et al. 2016a; Barth et al. 2017) and eelgrass (Jahnke et al. 2018). Jahnke et al. (2020) further combined genetics with dispersal models to identify sites for seagrass conservation in the same region.

Genetic methods can be used to directly estimate migration for species not affected by stocking. Using genetic markers with high coverage, the source population for individuals can be identified with high certainty. SNPs (Single Nucleotide Polymorphisms) associated with genes under selection has been used for stock identification in commercially fished species. For example, an individual cod can be assigned to the western or eastern Baltic Sea stock with high certainty (Nielsen et al. 2012). However, to date, genetic methods have only been used to study connectivity among MPAs or between MPAs and non-protected areas in a few cases worldwide, even though it is a promising tool (Jenkins and Stevens 2018). By identifying the origin of single individuals, migrants can be identified. It is also possible to use parentage analysis to identify where an individual's parents come from in order to 
determine if migrants also reproduce in new environments. For example in Swedish coastal and marine waters, the reproductive success of wild versus farmed salmon was studied (Dannewitz et al. 2004). However, using genetics to study connectivity directly requires rigorous sampling. If migration is low among populations or MPAs, many individuals need to be sampled in order to catch potential migrants. Furthermore, parentage analysis requires comprehensive sampling of the parent population. Nevertheless, there are also advantages to using genetic methods to study connectivity. Genetic markers are present within each individual and can be used as individual tags, without the requirement to undertake large tagging studies.

With information on relevant migration and dispersal distances, including both passive and active movement, modelling studies can be used to identify; (1) how large MPAs need to be in order to obtain viable populations, (2) important recruitment areas contributing to connectivity (connectivity hotspots), (3) optimum networks of MPAs, (4) optimal areas in which to extend the MPA network and (5) dispersal barriers to consider in MPA design. Evaluations of MPA networks in the Baltic Sea and KattegatSkagerrak have so far focused on larval dispersal. To evaluate the connectivity of MPA networks for species that disperse mainly through active movement, a distance-based method including active migration distances may be used. This primarily includes many coastal species with freshwater origin in the Baltic Sea, but also some marine fish and invertebrates. Such analyses have been done for pike, perch, pike-perch and roach in parts of the Baltic Sea (Sundblad et al. 2011) but could be applied to a larger area and more species when habitat maps become available. The distance-based method is appropriate for testing the coherence of MPAs in complex coastal environments with patchy habitat distribution and where the majority of species disperse by active migrations rather than passive dispersal. Habitat maps on migration corridors would also be very useful (Krost et al. 2018). However, maps and studies like these are lacking for both the Baltic Sea and KattegatSkagerrak.

In conclusion, there is a growing need to study dispersal dynamics among species, particularly invertebrates and non-commercial fishes. Studies combining various methods (tagging, otolith chemistry, genetics and modelling) are encouraged to gain a broader knowledge on both home ranges affecting population dynamics and maximum distances affecting genetic variation in populations. There is also a demand for comprehensive species distribution maps that can be used to perform spatial analyses on connectivity with both larval dispersal models and analyses of active migrations. Adequate habitat maps can be produced by species distribution modelling based on a thorough empirical sampling program, similar to in Virtanen et al.
(2018). Large-scale studies on larval dispersal have recently been performed in both the Baltic Sea and Kattegat-Skagerrak (Berglund et al. 2012; Corell et al. 2012; Moksnes et al. 2014b, 2016, Jonsson et al. 2016b; Hinrichsen et al. 2017a; Jonsson et al. 2020). In the future, evaluations including higher resolution hydrodynamics can be performed, enabling analysis of larval dispersal also in topographically complex coastal areas. Similarly, there is a need to perform comprehensive analyses on coastal species with short larval dispersal performing active migrations. This is true for both the Baltic Sea and Kattegat-Skagerrak. Furthermore, threats to ecological connectivity, including climate change and other human pressures like coastal development, that potentially limit dispersal between MPAs and lowers the resilience to environmental change, should be incorporated. These analyses can be used to identify areas of special importance for connectivity and to evaluate their sensitivity to different pressures, providing information for marine spatial planning, green infrastructure and habitat restoration.

Acknowledgements We wish to thank the Swedish Agency for Marine and Water Management (SwAM) for funding this project and Leonard Sandin for valuable comments on an earlier version of the manuscript. We also wish to thank Mårten Erlandsson for help with images and two anonymous reviewers for helpful comments.

Funding Open access funding provided by Swedish University of Agricultural Sciences. Funding was provided by Havs- och Vattenmyndigheten.

Open Access This article is licensed under a Creative Commons Attribution 4.0 International License, which permits use, sharing, adaptation, distribution and reproduction in any medium or format, as long as you give appropriate credit to the original author(s) and the source, provide a link to the Creative Commons licence, and indicate if changes were made. The images or other third party material in this article are included in the article's Creative Commons licence, unless indicated otherwise in a credit line to the material. If material is not included in the article's Creative Commons licence and your intended use is not permitted by statutory regulation or exceeds the permitted use, you will need to obtain permission directly from the copyright holder. To view a copy of this licence, visit http://creativecommons. org/licenses/by/4.0/.

\section{REFERENCES}

Allison, G.W., J. Lubchenco, and M.H. Carr. 1998. Marine reserves are necessary but not sufficient for marine conservation. Ecological Applications 8: S79-S92.

Álvarez-Romero, J.G., A. Munguía-Vega, M. Beger, M. Mar Mancha-Cisneros, A.N. Suárez-Castillo, G.G. Gurney, R.L. Pressey, L.R. Gerber, et al. 2018. Designing connected marine reserves in the face of global warming. Global Change Biology 24: e671-e691. 
Andersson, Å., S. Korpinen, A.-S. Liman, P. Nilsson, H. Piekäinen, and A. Huggins. 2008. Ecological coherence and principles for MPA assessment, selection and design. BALANCE Technical Summary Report PART 3/4.

Ardehed, A., D. Johansson, E. Schagerström, L. Kautsky, K. Johannesson, and R.T. Pereyra. 2015. Complex spatial clonal structure in the macroalgae Fucus radicans with both sexual and asexual recruitment. Ecology and Evolution 5: 4233-4245.

Ardehed, A., D. Johansson, L. Sundqvist, E. Schagerström, Z. Zagrodzka, N.A. Kovaltchouk, L. Bergström, L. Kautsky, et al. 2016. Divergence within and among Seaweed Siblings (Fucus vesiculosus and $F$. radicans) in the Baltic Sea. PLOS ONE 11: e0161266.

Ardron, J.A. 2008. Three initial OSPAR tests of ecological coherence: Heuristics in a data-limited situation. ICES Journal of Marine Science 65: 1527-1533.

Aro, E. 1989. A review of fish migration patterns in the Baltic. Rapp. P.-v. Réun. Cons. Int. Explor. Mer:72-96.

Aro, E. 2002. Fish migration studies in the Baltic Sea-A historical view. ICES Marine Science Symposia 215: 361-370.

Assis, J., E. Fragkopoulou, E.A. Serrão, B. Horta e Costa, M. Gandra, and D. Abecasis. 2021. Weak biodiversity connectivity in the European network of no-take marine protected areas. Science of the Total Environment 773: 145664.

Balbar, A.C., and A. Metaxas. 2019. The current application of ecological connectivity in the design of marine protected areas. Global Ecology and Conservation 17: e00569.

Bartolino, V., H. Tian, U. Bergström, P. Jounela, E. Aro, C. Dieterich, H.E.M. Meier, M. Cardinale, et al. 2017. Spatio-temporal dynamics of a fish predator: Density-dependent and hydrographic effects on Baltic Sea cod population. PLOS ONE 12: e0172004.

Barth, J.M.I., P.R. Berg, P.R. Jonsson, S. Bonanomi, H. Corell, J. Hemmer-Hansen, K.S. Jakobsen, K. Johannesson, et al. 2017. Genome architecture enables local adaptation of Atlantic cod despite high connectivity. Molecular Ecology 26: 4452-4466.

Baskett, M.L., and L.A.K. Barnett. 2015. The ecological and evolutionary consequences of marine reserves. Annual Review of Ecology, Evolution, and Systematics 46: 49-73.

Bekkevold, D., L. Jacobsen, J. Hemmer-Hansen, S. Berg, and C. Skov. 2015. From regionally predictable to locally complex population structure in a freshwater top predator: River systems are not always the unit of connectivity in Northern Pike Esox lucius. Ecology of Freshwater Fish 24: 305-316.

Benestan, L., K. Fietz, N. Loiseau, P.E. Guerin, E. Trofimenko, S. Rühs, C. Schmidt, W. Rath, et al. 2021. Restricted dispersal in a sea of gene flow. Proceedings of the Royal Society b: Biological Sciences 288: 20210458.

Berg, F., A. Slotte, A. Johannessen, C. Kvamme, L. W. Clausen, and R. D. M. Nash. 2017. Comparative biology and population mixing among local, coastal and offshore Atlantic herring (Clupea harengus) in the North Sea, Skagerrak, Kattegat and western Baltic. PLoS ONE 12:e0187374.

Berglund, M., M. Nilsson Jacobi, and P.R. Jonsson. 2012. Optimal selection of marine protected areas based on connectivity and habitat quality. Ecological Modelling 240: 105-112.

Bergström, L., S. Korpinen, U. Bergström, and Å. Andersson. 2007. Essential fish habitats and fish migration patterns in the Northern Baltic Sea. Balance Interim Report no. 29.

Bergström, L., A. Tatarenkov, K. Johannesson, R.B. Jönsson, and L. Kautsky. 2005. Genetic and morphological identification of Fucus radicans sp. Nov. (Fucales, Phaeophyceae) in the brackish Baltic Sea. Journal of Phycology 41: 1025-1038.

Boedeltje, G., T. Spanings, G. Flik, B.J.A. Pollux, F.A. Sibbing, and W.C.E.P. Verberk. 2015. Effects of seed traits on the potential for seed dispersal by fish with contrasting modes of feeding. Freshwater Biology 60: 944-959.

Botsford, L.W., J.W. White, M.A. Coffroth, C.B. Paris, S. Planes, T.L. Shearer, S.R. Thorrold, and G.P. Jones. 2009. Connectivity and resilience of coral reef metapopulations in marine protected areas: Matching empirical efforts to predictive needs. Coral Reefs 28: 327-337.

Bruno, J.F., A.E. Bates, C. Cacciapaglia, E.P. Pike, S.C. Amstrup, R. van Hooidonk, S.A. Henson, and R.B. Aronson. 2018. Climate change threatens the world's marine protected areas. Nature Climate Change 8: 499-503.

Candolin, U., and H.-R. Voigt. 2003. Size-dependent selection on arrival times in sticklebacks: Why small males arrive first. Evolution 57: 862-871.

Carr, M.H., S.P. Robinson, C. Wahle, G. Davis, S. Kroll, S. Murray, E.J. Schumacker, and M. Williams. 2017. The central importance of ecological spatial connectivity to effective coastal marine protected areas and to meeting the challenges of climate change in the marine environment. Aquatic Conservation: Marine and Freshwater Ecosystems 27: 6-29.

Claudet, J., C.W. Osenberg, L. Benedetti-Cecchi, P. Domenici, J.-A. García-Charton, A. Pérez-Ruzafa, F. Badalamenti, J. BayleSempere, et al. 2008. Marine reserves: Size and age do matter. Ecology Letters 11: 481-489.

Corell, H., P.O. Moksnes, A. Engqvist, K. Döös, and P.R. Jonsson. 2012. Depth distribution of larvae critically affects their dispersal and the efficiency of marine protected areas. Marine Ecology Progress Series 467: 29-46.

Corell, H., and A. Nissling. 2019. Modelling of larval dispersal of Baltic flounder (Platichthys solemdali) revealed drifting depth as a major factor determining opportunities for local retention vs large-scale connectivity. Fisheries Research 218: 127-137.

Cossellu, M., and K. Nordberg. 2010. Recent environmental changes and filamentous algal mats in shallow bays on the Swedish west coast-A result of climate change? Journal of Sea Research 63: 202-212.

Cowen, R.K., K.M.M. Lwiza, S. Sponaugle, C.B. Paris, and D.B. Olson. 2000. Connectivity of marine populations: Open or closed? Science 287: 857-859.

Cowen, R.K., C.B. Paris, and A. Srinivasan. 2006. Scaling of connectivity in marine populations. Science 311: 522-527.

Dannewitz, J., E. Petersson, J. Dahl, T. Prestegaard, A.-C. Löf, and T. Järvi. 2004. Reproductive success of hatchery-produced and wild-born brown trout in an experimental stream. Journal of Applied Ecology 41: 355-364.

De Wit, P., P.R. Jonsson, R.T. Pereyra, M. Panova, C. André, and K. Johannesson. 2020. Spatial genetic structure in a crustacean herbivore highlights the need for local considerations in Baltic Sea biodiversity management. Evolutionary Applications 13: 974-990.

Dinesen, G.E., S. Neuenfeldt, A. Kokkalis, A. Lehmann, J. Egekvist, K. Kristensen, P. Munk, K. Hüssy, et al. 2019. Cod and climate: A systems approach for sustainable fisheries management of Atlantic cod (Gadus morhua) in coastal Danish waters. Journal of Coastal Conservation 23: 943-958.

Donadi, S., Å.N. Austin, U. Bergström, B.K. Eriksson, J.P. Hansen, P. Jacobson, G. Sundblad, M. van Regteren, et al. 2017. A crossscale trophic cascade from large predatory fish to algae in coastal ecosystems. Proceedings of the Royal Society b: Biological Sciences 284: 20170045

Drenner, S.M., T.D. Clark, C.K. Whitney, E.G. Martins, S.J. Cooke, and S.G. Hinch. 2012. A synthesis of tagging studies examining the behaviour and survival of anadromous salmonids in marine environments. PLOS ONE 7: e31311.

Einfeldt, A.L., J.R. Doucet, and J.A. Addison. 2014. Phylogeography and cryptic introduction of the ragworm Hediste diversicolor 
(Annelida, Nereididae) in the Northwest Atlantic. Invertebrate Biology 133: 232-241.

Eklöf, J.S., G. Sundblad, M. Erlandsson, S. Donadi, J.P. Hansen, B.K. Eriksson, and U. Bergström. 2020. A spatial regime shift from predator to prey dominance in a large coastal ecosystem. Communications Biology 3: 459.

Eriander, L., E. Infantes, M. Olofsson, J.L. Olsen, and P.-O. Moksnes. 2016. Assessing methods for restoration of eelgrass (Zostera marina L.) in a cold temperate region. Journal of Experimental Marine Biology and Ecology 479: 76-88.

Eriander, L., K. Laas, P. Bergström, L. Gipperth, and P.-O. Moksnes. 2017. The effects of small-scale coastal development on the eelgrass (Zostera marina L.) distribution along the Swedish west coast - Ecological impact and legal challenges. Ocean \&amp; Coastal Management 148: 182-194.

Eriksson, B.K., A. Sandström, M. Isæus, H. Schreiber, and P. Karås. 2004. Effects of boating activities on aquatic vegetation in the Stockholm archipelago, Baltic Sea. Estuarine. Coastal and Shelf Science 61: 339-349.

European Commission. 2020. Communication from the commission to the European Parliament, The Council, The European Econmic and Social Committee and the Committee of Regions. EU Biodiversity Strategy for 2030 Bringing nature back into our lives. COM/2020/380 final. Brussels 20.05.2020. https://eur-lex. europa.eu/legal-content/EN/TXT/?qid=1590574123338\&uri= CELEX\%3A52020DC0380.

Faillettaz, R., C.B. Paris, and J.-O. Irisson. 2018. Larval fish swimming behavior alters dispersal patterns from Marine Protected Areas in the North-Western Mediterranean Sea. Frontiers in Marine Science 5: 97.

Félix-Hackradt, F.C., C.W. Hackradt, J. Treviño-Otón, Á. PérezRuzafa, and J.A. García-Charton. 2018. Effect of marine protected areas on distinct fish life-history stages. Marine Environmental Research 140: 200-209.

Fisher, R. 2005. Swimming speeds of larval coral reef fishes: Impacts on self-recruitment and dispersal. Marine Ecology Progress Series 285: 223-232.

Florin, A.B., U. Bergström, D. Ustups, K. Lundström, and P.R. Jonsson. 2013. Effects of a large northern European no-take zone on flatfish populations. Journal of Fish Biology 83: 939-962.

Florin, A.-B., and F. Franzén. 2010. Spawning site fidelity in Baltic Sea turbot (Psetta maxima). Fisheries Research 102: 207-213.

Florin, A.B., and J. Höglund. 2008. Population structure of flounder (Platichthys flesus) in the Baltic Sea: Differences among demersal and pelagic spawners. Heredity 101: 27-38.

Gagnaire, P.-A., T. Broquet, D. Aurelle, F. Viard, A. Souissi, F. Bonhomme, S. Arnaud-Haond, and N. Bierne. 2015. Using neutral, selected, and hitchhiker loci to assess connectivity of marine populations in the genomic era. Evolutionary Applications 8: 769-786.

Gaines, S.D., B. Gaylord, L.R. Gerber, A. Hastings, and B. Kinlan. 2007. Connecting places: The ecological consequences of dispersal in the sea. Oceanography 20: 90-99.

Goetze, J.S., S. Wilson, B. Radford, R. Fisher, T.J. Langlois, J. Monk, N.A. Knott, H. Malcolm, et al. 2021. Increased connectivity and depth improve the effectiveness of marine reserves. Global Change Biology 27: 3432-3447.

Green, A.L., L. Fernandes, G. Almany, R. Abesamis, E. McLeod, P.M. Aliño, A.T. White, R. Salm, et al. 2014. Designing marine reserves for fisheries management, biodiversity conservation, and climate change adaptation. Coastal Management 42: $143-159$

Göransson, P. 2017. Changes of benthic fauna in the Kattegat-An indication of climate change at mid-latitudes? Estuarine, Coastal and Shelf Science 194: 276-285.
Halpern, B.S., S.E. Lester, and K.L. McLeod. 2010. Placing marine protected areas onto the ecosystem-based management seascape. Proceedings of the National Academy of Sciences 107: 18312-18317.

Hammar, J., and M. Mattson. 2017. Potential climate refugia in the Baltic Sea based on two different scenarios-Information for marine spatial planning. Swedish Agency for Marine and Water Mangagement, Report 2017: 37 (In Swedish).

Hammersland, J., and J. e. Hjerpe Olausson. 2011. Reglering av fiske i skyddade havsområden. Swedish Environmental Protection Agency, Report 6416. (In Swedish, English summary)

Han, F., M. Jamsandekar, M.E. Pettersson, L.Y. Su, A.P. FuentesPardo, B.W. Davis, D. Bekkevold, F. Berg et al. 2020. Ecological adaptation in Atlantic herring is associated with large shifts in allele frequencies at hundreds of loci. eLife 9: E61076.

Hansen, J.P., G. Sundblad, U. Bergström, Å.N. Austin, S. Donadi, B.K. Eriksson, and J.S. Eklöf. 2018. Recreational boating degrades vegetation important for fish recruitment. Ambio 48: 539-551. https://doi.org/10.1007/s13280-018-1088-x.

Härmä, M., A. Lappalainen, and L. Urho. 2008. Reproduction areas of roach (Rutilus rutilus) in the northern Baltic Sea: Potential effects of climate change. Canadian Journal of Fisheries \&amp; Aquatic Sciences 65: 2678-2688.

Hattermann, D., M. Bernhardt-Römermann, A. Otte, and R.L. Eckstein. 2019. Geese are overlooked dispersal vectors for vascular plants in archipelago environments. Journal of Vegetation Science 30: 533-541.

HELCOM. 2010. Towards an ecologically coherent network of wellmanged Marine Protected Areas - Implementation report on the status and ecological coherence of the HELCOM BSPA network: Executive summary. Balt. Sea Environ. Proc. No. $124 \mathrm{~A}$.

HELCOM. 2016. Ecological coherence assessment of the Marine Protected Area network in the Baltic. Balt. Sea Environ. Proc. No. 148.

Hinrichsen, H.-H., W. Kühn, M.A. Peck, and R. Voss. 2012a. The impact of physical and biological factors on the drift and spatial distribution of larval sprat: A comparison of the Baltic and North Seas. Progress in Oceanography 107: 47-60.

Hinrichsen, H.-H., C. Petereit, A. Nissling, I. Wallin, D. Ustups, and A.-B. Florin. 2017a. Survival and dispersal variability of pelagic eggs and yolk-sac larvae of central and eastern baltic flounder (Platichthys flesus): Application of biophysical models. ICES Journal of Marine Science 74: 41-55.

Hinrichsen, H.H., K. Hüssy, and B. Huwer. 2012b. Spatio-temporal variability in western Baltic cod early life stage survival mediated by egg buoyancy, hydrography and hydrodynamics. ICES Journal of Marine Science 69: 1744-1752.

Hinrichsen, H.H., B. von Dewitz, A. Lehmann, U. Bergström, and K. Hüssy. 2017b. Spatio-temporal dynamics of cod nursery areas in the Baltic Sea. Progress in Oceanography 155: 28-40.

Holopainen, R., M. Lehtiniemi, H.E.M. Meier, J. Albertsson, E. Gorokhova, J. Kotta, and M. Viitasalo. 2016. Impacts of changing climate on the non-indigenous invertebrates in the northern Baltic Sea by end of the twenty-first century. Biological Invasions 18: 3015-3032.

Jahnke, M., P.R. Jonsson, P.O. Moksnes, L.O. Loo, J.M. Nilsson, and J.L. Olsen. 2018. Seascape genetics and biophysical connectivity modelling support conservation of the seagrass Zostera marina in the Skagerrak-Kattegat region of the eastern North Sea. Evolutionary Applications 11: 645-661.

Jahnke, M., P.-O. Moksnes, J.L. Olsen, N. Serra Serra, M. Nilsson Jacobi, K. Kuusemäe, H. Corell, and P.R. Jonsson. 2020. Integrating genetics, biophysical, and demographic insights 
identifies critical sites for seagrass conservation. Ecological Applications 30: e02121.

Jenkins, T.L., and J.R. Stevens. 2018. Assessing connectivity between MPAs: Selecting taxa and translating genetic data to inform policy. Marine Policy 94: 165-173.

Johannesson, K., and C. André. 2006. INVITED REVIEW: Life on the margin: Genetic isolation and diversity loss in a peripheral marine ecosystem, the Baltic Sea. Molecular Ecology 15: 2013-2029.

Johnson, D., J. Ardron, D. Billett, T. Hooper, and T. Mullier. 2013. An assessment of the ecological coherence of the OSPAR network of marine protected areas in 2012. OSPAR Report.

Johnson, D., J. Ardron, D. Billett, T. Hooper, T. Mullier, P. Chaniotis, B. Ponge, and E. Corcoran. 2014. When is a marine protected area network ecologically coherent? A case study from the North-east Atlantic. Aquatic Conservation: Marine and Freshwater Ecosystems 24: 44-58.

Jokinen, H., P. Momigliano, and J. Merilä. 2019. From ecology to genetics and back: The tale of two flounder species in the Baltic Sea. ICES Journal of Marine Science 76: 2267-2275.

Jonsson, P.R., H. Corell, C. André, H. Svedäng, and P.-O. Moksnes. 2016a. Recent decline in cod stocks in the North Sea-SkagerrakKattegat shifts the sources of larval supply. Fisheries Oceanography 25: 210-228.

Jonsson, P.R., J. Kotta, H.C. Andersson, K. Herkül, E. Virtanen, A.N. Sandman, and K. Johannesson. 2018. High climate velocity and population fragmentation may constrain climate-driven range shift of the key habitat former Fucus vesiculosus. Diversity and Distributions 24: 892-905.

Jonsson, P.R., P.-O. Moksnes, H. Corell, E. Bonsdorff, and M. Nilsson Jacobi. 2020. Ecological coherence of Marine Protected Areas: New tools applied to the Baltic Sea network. Aquatic Conservation: Marine and Freshwater Ecosystems 30: 743-760.

Jonsson, P.R., J.M. Nilsson, and P.O. Moksnes. 2016b. How to select networks of marine protected areas for multiple species with different dispersal strategies. Diversity and Distributions 22: $161-173$.

Jörgensen, H.B.H., M.M. Hansen, D. Bekkevold, D.E. Ruzzante, and V. Loeschcke. 2005. Marine landscapes and population genetic structure of herring (Clupea harengus L.) in the Baltic Sea. Molecular Ecology 14: 3219-3234.

Kallasvuo, M., J. Vanhatalo, and L. Veneranta. 2016. Modeling the spatial distribution of larval fish abundance provides essential information for management. Canadian Journal of Fisheries and Aquatic Sciences 74: 636-649.

King, R.A., R.J. Gornall, C.D. Preston, and J.M. Croft. 2002. Population differentiation of Potamogeton pectinatus in the Baltic Sea with reference to waterfowl dispersal. Molecular Ecology 11: 1947-1956.

Kinlan, B.P., and S.D. Gaines. 2003. Propagule dispersal in marine and terrestrial environments: A community perspective. Ecology 84: 2007-2020.

Koljonen, M.-L., J. Tähtinen, M. Säisä, and J. Koskiniemi. 2002. Maintenance of genetic diversity of Atlantic salmon (Salmo salar) by captive breeding programmes and the geographic distribution of microsatellite variation. Aquaculture 212: 69-92.

Krost, P., M. Goerres, and V. Sandow. 2018. Wildlife corridors under water: An approach to preserve marine biodiversity in heavily modified water bodies. Journal of Coastal Conservation 22: $87-104$

Källström, B., A. Nyqvist, P. Åberg, M. Bodin, and C. André. 2008. Seed rafting as a dispersal strategy for eelgrass (Zostera marina). Aquatic Botany 88: 148-153.

Laikre, L., L.M. Miller, A. Palmé, S. Palm, A.R. Kapuscinski, G. Thoresson, and N. Ryman. 2005. Spatial genetic structure of northern pike (Esox lucius) in the Baltic Sea. Molecular Ecology 14: 1955-1964.

Larsson, P., P. Tibblin, P. Koch-Schmidt, O. Engstedt, J. Nilsson, O. Nordahl, and A. Forsman. 2015. Ecology, evolution, and management strategies of northern pike populations in the Baltic Sea. Ambio 44: 451-461. https://doi.org/10.1007/s13280-0150664-6.

Leeuwen, C.H.A.V., Á. Lovas-Kiss, M. Ovegård, and A.J. Green. 2017. Great cormorants reveal overlooked secondary dispersal of plants and invertebrates by piscivorous waterbirds. Biology Letters 13: 20170406.

Leis, J.M. 2006. Are larvae of demersal fishes plankton or nekton? Advances in Marine Biology 51: 57-141.

Lester, S.E., B.S. Halpern, K. Grorud-Colvert, J. Lubchenco, B.I. Ruttenberg, S.D. Gaines, S. Airamé, and R.R. Warner. 2009. Biological effects within no-take marine reserves: A global synthesis. Marine Ecology Progress Series 384: 33-46.

Limborg, M.T., J.S. Pedersen, J. Hemmer-Hansen, J. Tomkiewicz, and D. Bekkevold. 2009. Genetic population structure of European sprat Sprattus sprattus: Differentiation across a steep environmental gradient in a small pelagic fish. Marine Ecology Progress Series 379: 213-224.

Lovas-Kiss, Á., O. Vincze, V. Löki, F. Pallér-Kapusi, B. HalasiKovács, G. Kovács, A.J. Green, and B.A. Lukács. 2020. Experimental evidence of dispersal of invasive cyprinid eggs inside migratory waterfowl. Proceedings of the National Academy of Sciences 117: 15397-15399.

Lowe, W.H., and F.W. Allendorf. 2010. What can genetics tell us about population connectivity? Molecular Ecology 19: 3038-3051.

Lubchenco, J., S.R. Palumbi, S.D. Gaines, and S. Andelman. 2003. Plugging a hole in the ocean: The emerging science of marine reserves. Ecological Applications 13: 3-7.

Macura, B., P. Byström, L. Airoldi, B.K. Eriksson, L. Rudstam, and J.G. Støttrup. 2019. Impact of structural habitat modifications in coastal temperate systems on fish recruitment: A systematic review. Environmental Evidence 8: 14.

Magris, R.A., R.L. Pressey, R. Weeks, and N.C. Ban. 2014. Integrating connectivity and climate change into marine conservation planning. Biological Conservation 170: 207-221.

Martínez-García, L., B. Hansson, and J. Hollander. 2021. Assessment of local genetic structure and connectivity of the common eelgrass Zostera marina for seagrass restoration in northern Europe. Marine Ecology Progress Series 664: 103-116.

Micheli, F., A. Saenz-Arroyo, A. Greenley, L. Vazquez, J.A. Espinoza Montes, M. Rossetto, and G.A. De Leo. 2012. Evidence that marine reserves enhance resilience to climatic impacts. PLOS ONE 7: e40832.

Momigliano, P., G.P.J. Denys, H. Jokinen, and J. Merilä. 2018. Platichthys solemdali sp. nov. (Actinopterygii, Pleuronectiformes): A new flounder species from the Baltic Sea. Frontiers in Marine Science 5: 225.

Moksnes, P.-O., H. Corell, K. Tryman, R. Hordoir, and P.R. Jonsson. 2014a. Larval behavior and dispersal mechanisms in shore crab larvae (Carcinus maenas): Local adaptations to different tidal environments? Limnology and Oceanography 59: 588-602.

Moksnes, P.O., P.R. Jonsson, M. Nilsson Jacobi, and K. Vikström. 2014b. Larval connectivity and ecological coherence of marine protected areas (MPAs) in the Kattegat-Skagerrak region. Swedish Institute for the Marine Environment. Report.

Moksnes, P.O., M. Nilsson Jacobi, and P. Jonsson. 2015. Identifying new areas adding larval connectivity to existing networks of MPAs. Swedish Agency for Marine and Water Managment Report 2015: 24. 
Molloy, P.P., I.B. McLean, and I.M. Côté. 2009. Effects of marine reserve age on fish populations: A global meta-analysis. Journal of Applied Ecology 46: 743-751.

Nielsen, E.E., A. Cariani, E.M. Aoidh, G.E. Maes, I. Milano, R. Ogden, M. Taylor, J. Hemmer-Hansen, et al. 2012. Geneassociated markers provide tools for tackling illegal fishing and false eco-certification. Nature Communications 3: 851.

Nilsson, J., O. Engstedt, and P. Larsson. 2014. Wetlands for northern pike (Esox lucius L.) recruitment in the Baltic Sea. Hydrobiologia 721: 145-154.

Nilsson Jacobi, M., C. André, K. Döös, and P.R. Jonsson. 2012. Identification of subpopulations from connectivity matrices. Ecography 35: 1-13.

Nissling, A., S. Nyberg, and C. Petereit. 2017. Egg buoyancy of flounder, Platichthys flesus, in the Baltic Sea-Adaptation to salinity and implications for egg survival. Fisheries Research 191: 179-189.

Nissling, A., and I. Wallin. 2020. Recruitment variability in Baltic flounder (Platichthys solemdali) -Effects of salinity with implications for stock development facing climate change. Journal of Sea Research 162: 101913.

Olsson, J., L. Bergström, and A. Gårdmark. 2012a. Abiotic drivers of coastal fish community change during four decades in the Baltic Sea. ICES Journal of Marine Science 69: 961-970.

Olsson, J., A.-B. Florin, K. Mo, T. Aho, and N. Ryman. 2012b. Genetic structure of whitefish (Coregonus maraena) in the Baltic Sea. Estuarine, Coastal and Shelf Science 97: 104-113.

Olsson, J., K. Mo, A.B. Florin, T. Aho, and N. Ryman. 2011. Genetic population structure of perch Perca fluviatilis along the Swedish coast of the Baltic Sea. Journal of Fish Biology 79: 122-137.

Øresland, V., and M. Ulmestrand. 2013. European lobster subpopulations from limited adult movements and larval retention. ICES Journal of Marine Science 70: 532-539.

Orio, A., U. Bergström, M. Casini, M. Erlandsson, R. Eschbaum, K. Hüssy, A. Lehmann, L. Ložys, et al. 2017. Characterizing and predicting the distribution of Baltic Sea flounder (Platichthys flesus) during the spawning season. Journal of Sea Research 126: $46-55$.

Orio, A., U. Bergström, A.-B. Florin, A. Lehmann, I. Šics, and M. Casini. 2019. Spatial contraction of demersal fish populations in a large marine ecosystem. Journal of Biogeography 46: 633-645.

Ortodossi, N.L., B.L. Gilby, T.A. Schlacher, R.M. Connolly, N.A. Yabsley, C.J. Henderson, and A.D. Olds. 2019. Effects of seascape connectivity on reserve performance along exposed coastlines. Conservation Biology 33: 580-589.

Östergren, J., J. Nilsson, and H. Lundqvist. 2012. Linking genetic assignment tests with telemetry enhances understanding of spawning migration and homing in sea trout Salmo trutta L. Hydrobiologia 691: 123-134.

Palumbi, S.R. 2004. Marine reserves and ocean neighborhoods: The spatial scale of marine populations and their management. Annual Review of Environment and Resources 29: 31-68.

Pereyra, R.T., C. Huenchuñir, D. Johansson, H. Forslund, L. Kautsky, P.R. Jonsson, and K. Johannesson. 2013. Parallel speciation or long-distance dispersal? Lessons from seaweeds (Fucus) in the Baltic Sea. Journal of Evolutionary Biology 26: 1727-1737.

Perry, D., T.A.B. Staveley, and M. Gullström. 2018. Habitat connectivity of fish in temperate shallow-water seascapes. Frontiers in Marine Science 4: 440.

Piekäinen, and S. Korpinen. 2007. Towards ecological coherence of the MPA network in the Baltic Sea. Balance Interim Report No. 25 .

Pihl, L., J. Modin, and H. Wennhage. 2005. Relating plaice (Pleuronectes platessa) recruitment to deteriorating habitat quality: Effects of macroalgal blooms in coastal nursery grounds.
Canadian Journal of Fisheries and Aquatic Sciences 62: 1184-1193.

Planes, S., G.P. Jones, and S.R. Thorrold. 2009. Larval dispersal connects fish populations in a network $\mathrm{f}$ marine protected areas. Proceedings of the National Academy of Sciences. 106: 5693-5697.

Rees, S.E., S.J. Pittman, N. Foster, O. Langmead, C. Griffiths, S. Fletcher, D.E. Johnson, and M. Attrill. 2018. Bridging the divide: Social-ecological coherence in Marine Protected Area network design. Aquatic Conservation: Marine and Freshwater Ecosystems 28: 754-763.

Reusch, T. B. H., J. Dierking, H. C. Andersson, E. Bonsdorff, J. Carstensen, M. Casini, M. Czajkowski, B. Hasler et al. Science Advances 4:eaar8195.

Ross, R.E., W.A.M. Nimmo-Smith, and K.L. Howell. 2017. Towards 'ecological coherence': Assessing larval dispersal within a network of existing Marine Protected Areas. Deep Sea Research Part i: Oceanographic Research Papers 126: 128-138.

Rothäusler, E., H. Corell, and V. Jormalainen. 2015. Abundance and dispersal trajectories of floating Fucus vesiculosus in the Northern Baltic Sea. Limnology and Oceanography 60: 2173-2184.

Rönnbäck, P., N. Kautsky, L. Pihl, M. Troell, T. Söderqvist, and H. Wennhage. 2007. Ecosystem goods and services from Swedish coastal habitats: Identification, valuation, and implications of ecosystem shifts. Ambio 36: 534-544. https://doi.org/10.1579/ 0044-7447(2007)36

Sandström, A., B.K. Eriksson, P. Karås, M. Isæus, and H. Schreiber. 2005. Boating and navigation activities influence the recruitment of fish in a Baltic Sea archipelago area. Ambio 34 (125-130): 126. https://doi.org/10.1579/0044-7447-34.2.125.

Saulamo, K., and E. Neuman. 2002. Local management of Baltic fish stocks-Significance of migrations. The Swedish Board of Fisheries, Report Finfo 2002:9, 1-18.

Seitz, R.D., H. Wennhage, U. Bergström, R.N. Lipcius, and T. Ysebaert. 2014. Ecological value of coastal habitats for commercially and ecologically important species. ICES Journal of Marine Science 71: 648-665.

Snickars, M., G. Sundblad, A. Sandström, L. Ljunggren, U. Bergström, G. Johansson, and J. Mattila. 2010. Habitat selectivity of substrate-spawning fish: Modelling requirements for the Eurasian perch Perca fluviatilis. Marine Ecology Progress Series 398: 235-243.

Staveley, T.A.B., D. Perry, R. Lindborg, and M. Gullström. 2016. Seascape structure and complexity influence temperate seagrass fish assemblage composition. Ecography 40: 936-946.

Steneck, R.S., C.B. Paris, S.N. Arnold, M.C. Ablan-Lagman, A.C. Alcala, M.J. Butler, L.J. McCook, G.R. Russ, and P.F. Sale. 2009. Thinking and managing outside the box: Coalescing connectivity networks to build region-wide resilience in coral reef ecosystems. Coral Reefs 28: 367-378.

Sundblad, G., and U. Bergström. 2014. Shoreline development and degradation of coastal fish reproduction habitats. Ambio 43: 1020-1028. https://doi.org/10.1007/s13280-014-0522-y.

Sundblad, G., U. Bergström, and A. Sandström. 2011. Ecological coherence of marine protected area networks: A spatial assessment using species distribution models. Journal of Applied Ecology 48: 112-120.

Tatarenkov, A., L. Bergstrom, R.B. Jonsson, E.A. Serrao, L. Kautsky, and K. Johannesson. 2005. Intriguing asexual life in marginal populations of the brown seaweed Fucus vesiculosus. Molecular Ecology 14: 647-651.

Thorson, G. 1950. Reproductive and larval ecology of marine bottom invertebrates. Biological Reviews 25: 1-45.

Tibblin, P., A. Forsman, T. Borger, and P. Larsson. 2016. Causes and consequences of repeatability, flexibility and individual fine- 
tuning of migratory timing in pike. Journal of Animal Ecology 85: $136-145$

Tibblin, P., P. Koch-Schmidt, P. Larsson, and P. Stenroth. 2012. Effects of salinity on growth and mortality of migratory and resident forms of Eurasian perch in the Baltic Sea. Ecology of Freshwater Fish 21: 200-206.

Ulrich, C., J. Hemmer-Hansen, J. Boje, A. Christensen, K. Hüssy, H. Sun, and L.W. Clausen. 2017. Variability and connectivity of plaice populations from the Eastern North Sea to the Baltic Sea, part II. Biological evidence of population mixing. Journal of Sea Research 120: 13-23.

Ungfors, A., H. Hallbäck, and P.G. Nilsson. 2007. Movement of adult edible crab (Cancer pagurus L.) at the Swedish West Coast by mark-recapture and acoustic tracking. Fisheries Research 84: 345-357.

Vandeperre, F., R.M. Higgins, J. Sánchez-Meca, F. Maynou, R. Goñi, P. Martín-Sosa, A. Pérez-Ruzafa, P. Afonso, et al. 2011. Effects of no-take area size and age of marine protected areas on fisheries yields: A meta-analytical approach. Fish and Fisheries 12: 412-426.

Vasemägi, A., R. Gross, T. Paaver, M.L. Koljonen, and J. Nilsson. 2005. Extensive immigration from compensatory hatchery releases into wild Atlantic salmon population in the Baltic sea: Spatio-temporal analysis over 18 years. Heredity 95: 76.

Veneranta, L., R. Hudd, and J. Vanhatalo. 2013. Reproduction areas of sea-spawning coregonids reflect the environment in shallow coastal waters. Marine Ecology Progress Series 477: 231-250.

Viitasalo, M. 2019. Impacts of climate change on the ecosystem of the Baltic Sea. Oxford: Oxford University Press.

Virtanen, E.A., M. Viitasalo, J. Lappalainen, and A. Moilanen. 2018. Evaluation, gap analysis, and potential expansion of the Finnish marine protected area network. Frontiers in Marine Science 5: 402.

Wake, B. 2012. Climate and Baltic Sea nutrients. Nature Climate Change 2: 394.

Weeks, R. 2017. Incorporating seascape connectivity in conservation prioritisation. PLOS ONE 12: e0182396.

Wennerström, L., E. Jansson, and L. Laikre. 2017. Baltic Sea genetic biodiversity: Current knowledge relating to conservation management. Aquatic Conservation: Marine and Freshwater Ecosystems. https://doi.org/10.1002/aqc.2771.

Wennerström, L., J. Olsson, N. Ryman, and L. Laikre. 2016. Temporally stable, weak genetic structuring in brackish water northern pike (Esox lucius) in the Baltic Sea indicates a contrasting divergence pattern relative to freshwater populations. Canadian Journal of Fisheries and Aquatic Sciences 74: $562-571$.

Werner, K.M., A. Staby, and A.J. Geffen. 2016. Temporal and spatial patterns of reproductive indices of European hake (Merluccius merluccius) in the northern North Sea and Norwegian coastal areas. Fisheries Research 183: 200-209.

Wilson, K.L., D.P. Tittensor, B. Worm, and H.K. Lotze. 2020. Incorporating climate change adaptation into marine protected area planning. Global Change Biology 26: 3251-3267.

Winston, J.E. 2012. Dispersal in marine organisms without a pelagic larval phase. Integrative and Comparative Biology 52: 447-457.

Wolters, H., I. Galparsoro, R. Castro, S. Korpinen, M. Nurmi, C. Tsangaris, S. Reizopoulou, M. van der Meulen et al. 2015. Proposal for an assessment method of the ecological coherence of networks of marine protected areas in Europe. Report 1208917-000-ZKS-0018, pp. 123 https://doi.org/10.13140/RG. 2.1.2382.8969.

Publisher's Note Springer Nature remains neutral with regard to jurisdictional claims in published maps and institutional affiliations.

\section{AUTHOR BIOGRAPHIES}

Charlotte Berkström $(\square)$ is an Associate Professor at the Swedish University of Agricultural Sciences. Her research interests include: ecological connectivity, seascape ecology, marine protected areas, ecosystem based management

Address: Department of Aquatic Resources, Swedish University of Agricultural Sciences, Institute of Coastal Research, Skolgatan 6, 742 42 Öregrund, Sweden.

e-mail: charlotte.berkstrom@slu.se

Lovisa Wennerström is an Environmental Assessment Specialist at the Swedish University of Agricultural Sciences. Her research interests include: population and conservation genetics, environmental assessment, fisheries science

Address: Department of Aquatic Resources, Swedish University of Agricultural Sciences, Institute of Coastal Research, Skolgatan 6, 742 42 Öregrund, Sweden.

e-mail: lovisa.wennerstrom@slu.se

Ulf Bergström is an Associate Professor at the Swedish University of Agricultural Sciences. His research interests include: species distribution modelling, food-web interactions, marine spatial planning, marine protected areas, ecosystem-based management

Address: Department of Aquatic Resources, Swedish University of Agricultural Sciences, Institute of Coastal Research, Skolgatan 6, 742 42 Öregrund, Sweden.

e-mail: ulf.bergstrom@slu.se 